\title{
Photography as Event: Power, the Kodak Camera, and Territoriality in Early Twentieth-Century Tibet
}

\author{
SIMEON KOOLE \\ University of Oxford
}

At the edge of the Roof of the World in July 1903, four Chinese soldiers prepared, reluctantly, to be photographed (figure 1). The scene might have been comical were it not so obviously involuntary. A Sikh soldier of the British Army holds the line while another wrestles a subject into place; the Chinese "were afraid of the camera," the caption explains, "and had to be collected by the Sikhs of the Pioneers." The claim that Chinese and Tibetan soldiers were afraid of photography was a well-worn colonial stereotype, but their forced involvement in it here was real. As a record of the act of photographing, rather than only the end product, this photograph seems to show the power "behind" the camera. It seems to show the inequality of power between those photographing and those photographed, the traces of which would be erased by the final "official" photograph.

Yet there remains a resistant banality to this photograph, irreducible to an explanation of who had power in the photograph and who did not. To the left of the tussle one of the Chinese soldiers indifferently smiles while adjusting his hat; another wanders out of the frame, trailed by an inquisitive dog. Even this photograph, which apparently reveals the instrumentalization that photography normally conceals, contains elements that stubbornly, mundanely, resist the meaning that the Sikh soldiers try to impose on it. If this photograph unveils photography's instrumentalizing impulse, it is an impulse that is never fully realized. It is not just that the Chinese soldiers resist their Sikh counterparts,

\footnotetext{
Acknowledgments: I am grateful to Sujit Sivasundaram, Tom Simpson, and Clare Harris for their suggestions in response to earlier drafts of this paper, and to Ariella Azoulay and Christopher Pinney for their comments at the conference Visuality and Territoriality in South Asia, University of Oxford, June 2014. Hildegard Diemberger, Fiona McConnell, and Emma Martin offered invaluable advice on Tibetan Studies. The paper also benefited from the careful attention of the anonymous CSSH reviewers and by the editor David Akin. Thank you.
} 


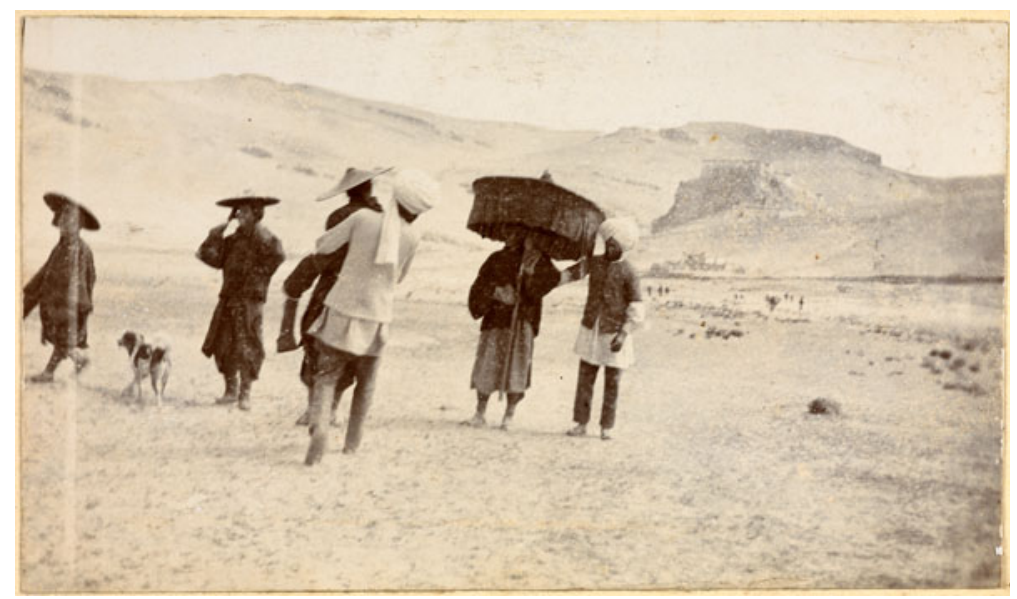

FiguRE 1 Frederick Bailey, "Photographing Chinese soldiers-They were afraid of the camera, and had to be collected by the Sikhs of the Pioneers. (14.7.03)." Source: unpublished photograph album, Tibet 1903-4, (c) British Library Board, photo/1083/12 (34), British Library, London.

but that there is an intrinsic indeterminacy in the event itself, resistant to the control of any of its participants. ${ }^{1}$ The jocular tilting of the hat, the misplaced dog; these are not incidental to the photograph's power relations - they are integral to them.

These apparent trivialities, occurring at a time of exceptional political change for Tibet, offer a starting point for engaging with the wide-ranging debates on the nature of power and agency in photography and its relation to territorial space. The inscrutability of these incidental details suggests the need to think about power as something produced in, received through, and distributed across the photographic event itself, across its surface, rather than as an object lying "behind," brought to, and "contested" during it, as if the event were a play that only articulated what had already been decided offstage. Rather than expressing an opposition between competing parties pre-existing the event itself and "possessing" power, photography was, I argue, a proposition through which those parties produced power and constituted themselves in relation to each other and to the concept of Tibet as a political entity. It was an event that proposed, rather than foreclosed, potential ways of being politically "Tibetan" during a period when the meaning of that term was especially hotly disputed.

1 Ariella Azoulay, Civil Imagination: A Political Ontology of Photography, Louise Bethlehem, trans. (London, 2012), 14-15. I have found Azoulay's theorization of photography especially influential and engage with it throughout this paper. See also Robin Kelsey, Photography and the Art of Chance (London, 2015), 6-11. 
The year 1904 was a turbulent one for Tibet. It marked a rupture in Tibet's underlying definition, or lack of definition, as an autonomous state as well as in the means of visually reproducing and reflecting upon that definition. The photograph of Chinese soldiers - not just any soldiers but the retinue of the delegate sent by the amban (Chinese resident) in Lhasa-being manhandled by Sikh Pioneers of a belligerent British expedition testifies to these convergent political and technological transformations. It was the crest of a wave of photographs taken in Tibet over the following years, the first of any significant number, which were fragments of a global geopolitical shift at the intersection of the British, Russian, and Chinese empires. As the Qing Empire disintegrated and British and Russian soldier-diplomats converged on Tibet, photography offered a new opportunity for defining Tibetan autonomy, but one that was unpredictable, indeterminate, and accessible to all participants in the photographic event, much like the concept of Tibet that it produced. As well as demanding a critical reassessment of agency in photography, the photographs taken in 1903 and 1904 therefore compel a rethinking of Tibet itself as an object of study. They suggest that Tibet was a proposition, a constellation of interactions contingent on each photographic event, not an object of opposition preexisting or "constructed" through that event. I argue that they point to the need to think about power in photography and about Tibet's temporal existence in terms of a more radical contingency, to think, in Nietzsche's terms, "unhistorically" in order to think truly historically. ${ }^{2}$

\section{THE LIMITS OF INSTRUMENTALITY}

For nearly two centuries Tibet had ostensibly been under Chinese "suzerainty." Contemporary British politicians used the term to describe Tibet's subordination to China, a description that, historian Elliot Sperling argues, ipso facto reified that subordination to delegitimize Russian involvement in the region. The term is not used in current official PRC or Tibetan scholarship, for divergent ideological reasons, but serves us here as a useful placeholder for the growing Chinese entanglement in Tibet marked by the establishment in 1720 of a dual Sino-Tibetan government. ${ }^{3}$ From this point, the secular branch of the Tibetan government, directed by a kashag (council) of four shapes

\footnotetext{
2 Friedrich Nietzsche, "On the Uses and Disadvantages of History for Life," in Untimely Meditations, Daniel Breazeale, ed., R. J. Hollingdale, trans. (Cambridge, 1997), 120.

3 PRC scholarship prefers to see Tibet as always having been "integral" to China rather than a "vassal state" of the Chinese Empire. Tibetan scholarship instead claims that Tibet's relation to China was one of a priest to a patron (mchod-yon); a personal relationship between the Dalai Lama and the emperor in which the former offered spiritual guidance and the latter provided protection with neither dominance nor subordination. Elliot Sperling, The Tibet-China Conflict: History and Polemics (Washington, D.C., 2004), 6-9, 16-19; Matthew Kapstein, The Tibetans (Malden, 2006), 146-50; D. Seyfort Ruegg, "mchod yon, yon mchod, and mchod gnas/yon gnas: On the Historiography and Semantics of a Tibetan Religio-Social and Religio-Political Concept," in Alex McKay, ed., The History of Tibet, 3 vols. (London, 2003), II, 366-68.
} 
(ministers) and formerly under the exclusive authority of the Dalai Lama, was also under the jurisdiction of two Chinese ambans representing the interests of the Qing emperor. ${ }^{4}$ Although the degree to which ambans were able to influence Tibetan politics is contested, there is no doubt that they made Chinese power felt most during the not infrequent minorities of the Dalai Lama, when Tibet was governed by a regent. ${ }^{5}$

But from the Opium Wars (1839-1842 and 1856-1860) onward, the gradual weakening of the Qing Empire caused this control to slip. China's failure to repel a Nepalese invasion of Tibet in 1854 convinced the Tibetan government that when the frontier was next threatened unilateral action would be necessary. After British soldiers expelled Tibetans occupying Giagong, Sikkim, in 1888, a general conscription of Tibetan soldiers was launched and oaths taken to defend Tibet, regardless of Chinese support. ${ }^{6}$ Similarly, contrary to the Anglo-Chinese Chefoo Treaty (1876), which guaranteed freedom of access for European missions to Tibet, a new policy of excluding European visitors developed over the late nineteenth century. ${ }^{7}$ While it is unclear whether this was a Tibetan or Chinese policy, the Tibetan government's apparent rejection of China's authority to conclude treaties on its behalf revealed the increasingly illusory nature of Chinese suzerainty. ${ }^{8}$ From the 1890 s, an increasingly assertive Dalai Lama initiated his own diplomatic missions to Russia in the face of Chinese collapse. Between 1898 and 1901 three Tibetan embassies sought the patronage of Tsar Nicholas II, already the protector of Buriat and Kalmyk Buddhists of the Trans-Baikal region associated with the Gelukpa school of Tibetan Buddhism, over which the Dalai Lama presided. ${ }^{9}$ When reports of these missions coincided with the Dalai Lama's refusal to open British diplomatic correspondence in 1901, Viceroy Lord Curzon perceived a new threat at British India's border. ${ }^{10}$ Fearing that cozier relations with Tibet gave Russia the potential to foment unrest below the Himalayas, in 1903 Curzon commissioned

${ }^{4}$ Luciano Petech, Aristocracy and Government in Tibet, 1728-1959 (Rome, 1973), 7-10.

5 Warren W. Smith Jr., China's Tibet? Autonomy or Assimilation (Lanham, 2008), 8. For an example, see Charles Bell, Portrait of the Dalai Lama: The Life and Times of the Great Thirteenth (London, 1946), 53-54.

${ }^{6}$ Henry Sanderson, "Transgression of the Frontier: An Analysis of Documents Relating to the British Invasion of Tibet," Inner Asia 14 (2012): 32-33. Dalai Lamas reach their majority at age eighteen.

7 Official exclusion of Europeans in practice applied only to central Tibet, however. Alex McKay, "Tibet and the Myth of Isolation," in Alex McKay, ed., The History of Tibet, 3 vols. (London, 2003), III, 638-39.

${ }^{8}$ McKay argues, though, that isolationism equally served Chinese purposes by, for example, suppressing possible competition threatened by British Indian tea from Darjeeling; "Tibet and the Myth of Isolation”, 637.

9 Alastair Lamb, British India and Tibet, 1766-1910 (London, 1986), 183, 205-9; T. L. Shaumian, Tibet: The Great Game and Tsarist Russia (New Delhi, 2000), 16-17. See also Alexander Andreyev, "Russian Buddhists in Tibet, from the End of the Nineteenth Century-1930," Journal of the Royal Asiatic Society 11, 3 (2001): 349-62.

${ }^{10}$ Lamb, British India and Tibet, 196-209. 
officer-explorer Colonel Francis Younghusband to change the Dalai Lama's mind. The Younghusband expedition entered Tibet in July 1903 and reached Lhasa in August 1904; ostensibly a trade mission, it became a military advance with the addition of a battalion of the Royal Fusiliers and six companies of Indian soldiers. ${ }^{11}$

These soldiers were armed with not only rifles but also cameras. The second in command, British Resident of Sikkim John Claude White, lugged a $13 \times 10$ inch camera (probably a Thornton-Pickard Royal Ruby) to officially record the journey, and most others sported lightweight Folding Pocket Kodaks, first introduced in $1895 .^{12}$ Several officers had the FPK3, introduced in 1900, but writing home during the expedition, Lieutenant Frederick Bailey requested a FPK3A, a newer model released in May 1903, which was "very much advertised now." Bailey's letter was only sent on 30 October 1903; and even while in Tibet the expedition kept abreast with the latest advances from Kodak, via routes that I will explain later. ${ }^{13}$

The year 1895 also brought Japan's crushing defeat of China and, perhaps not coincidentally, the first time a Dalai Lama had reached his majority and survived in ninety-one years. Upon his accession the Thirteenth Dalai Lama, Thubten Gyatso (1876-1933), fostered a more muscular, assertive role for Tibet. The embassies to Russia were part of this, but so too was a 1901 proclamation outlining the responsibilities of government officers and monks towards the laity - aimed at convincing foreign governments that an autonomous Tibet had its house in order - and the creation of an arsenal for a "Tibetan national army." These were the beginnings of the formulation of Tibet as an independent nation-state. ${ }^{14}$

There was more than accident in this conjuncture of flexible photography and an increasingly autonomous Tibet. But the relation was not one of photography being used to contest, construct, or compel versions of Tibetan autonomy. It is tempting to follow the lead of Bishop, who argues that photographs "gave Westerners a vicarious sense of power over Tibet," that photography "helped to fix Tibet [...] to establish a kind of one-way communication." 15 For the sake of British India's security, Curzon wanted Tibetan

11 Charles Allen, Duel in the Snows: The True Story of the Younghusband Mission to Lhasa (London, 2004), 178-79.

12 Pamela Deuel Meyer and Kurt Meyer, In the Shadow of the Himalayas: Tibet, Bhutan, Nepal, Sikkim: A Photographic Record by John Claude White, 1883-1908 (Ahmedabad, 2005), 9.

13 Frederick Bailey, Letters, 30 Oct. and 17 Nov. 1903, British Library, MSS Eur F157/163. On the FPK3 camera, see Anglo-Boer War correspondent H. Shelley's How to Buy a Camera (London, 1902), 28-29; Michael Pritchard, A History of Photography in 50 Cameras (London, 2014), 52.

14 T. Chhodak, "The 1901 Proclamation of H. H. Dalai Lama XIII," in Alex McKay, ed., The History of Tibet, 3 vols. (London, 2003), III, 39-40; Gray Tuttle, Faith and Nation: Tibetan Buddhists in the Making of Modern China (New York, 2005), 39.

15 Peter Bishop, The Myth of Shangri-La: Tibet, Travel-Writing and the Western Creation of Sacred Landscape (London, 1989), 189. 
autonomy as much as the Dalai Lama did, and White's photography, echoed by other officers, was ostensibly one way of reifying it. This argument fits into well-established narratives of Tibet as a discursive construct (Shangri-La) and of colonial photography as instrumentalizing its subjects in order to construct subordinate political imaginaries. ${ }^{16}$ It is part of a wider and even more established understanding of photography as producing the reality it purports only to record, reproducing a regime of truth and asymmetrical power relations through a fictive objectivity. ${ }^{17}$ This is more convincing than accounts assuming Tibet was pre-given as a political entity, something the expedition simply marched across. ${ }^{18}$ But it turns the subjects of photography-Tibetans-into only effects of power relations that pre-existed it rather than participants in the production of those relations and the political imaginaries that resulted. ${ }^{19}$ The task becomes a "hermeneutics of suspicion," where the historian peels back the photograph's "false" transparent objectivity to reveal the "true" instrumentalizing purpose of the photographer "behind" it. ${ }^{20}$

Attention to the variegated ways in which photographs were produced and consumed addresses some of these problems. Harris, for example, differentiates between photographs taken by the expedition's rank-and-file members and

16 Donald Lopez, Prisoners of Shangri-La: Tibetan Buddhism and the West (Chicago, 1998); Alex McKay, "'Truth,' Perception, and Politics: The British Construction of an Image of Tibet," in Thierry Dodin and Heinz Räther, eds., Imagining Tibet: Perception, Projections, and Fantasies (Boston, 2001), 83-84. For the instrumentalizing power of colonial photography, see for example James Ryan, Picturing Empire: Photography and the Visualisation of the British Empire (London, 1997). For photography as a colonial propaganda tool, see Peter Harrington, "Pictorial Journalism and the Boer War: The London Illustrated Weeklies," in John Gooch, ed., The Boer War: Direction, Experience, and Image (London, 2000), 224-44. The relation between photography and colonial power is readdressed in Martin Jay and Sumathi Ramaswamy, eds., Empires of Vision: A Reader (Durham, 2014), though the volume sometimes slips back to a model of the gaze along an axis of dominance and resistance.

17 Elizabeth Edwards, "Tracing Photography," in Marcus Banks and Jay Ruby, eds., Made to Be Seen: Perspectives on the History of Visual Anthropology (Chicago, 2011), 170-72. Exemplars include Pierre Bourdieu, Photography: A Middle-Brow Art, Shaun Whiteside, trans. (Cambridge, 1990); David Green, "Veins of Resemblance: Photography and Eugenics," Oxford Art Journal 7 (1984): 3-16; Jennifer Green-Lewis, Framing the Victorians: Photography and the Culture of Realism (Ithaca, 1996); Allan Sekula, "The Body and the Archive," October 39 (1986): 3-64; John Tagg, The Burden of Representation: Essays on Photographies and Histories (Basingstoke, 1988).

${ }_{18}$ Premen Addy, Tibet on the Imperial Chessboard: The Making of British Policy towards Lhasa, 1899-1925 (Calcutta, 1984); Charles Allen, Duel in the Snows: The True Story of the Younghusband Mission to Lhasa (London, 2004); Peter Fleming, Bayonets to Lhasa: The First Full Account of the British Invasion of Tibet in 1904 (London, 1961). For critiques, see Stuart Elden, The Birth of Territory (Chicago, 2013), 1-18, 322-30; Neil Brenner, "Beyond State-Centrism? Space, Territoriality, and Geographical Scale in Globalization Studies," Theory and Society 28 (1999): 39-78.

19 Edwards, "Tracing Photography," 172-75.

20 Paul Ricoeur, Freud and Philosophy: An Essay on Interpretation, Denis Savage, trans. (New Haven, 1970), 32-36. For photographic theory's "mistrust" of photography's power/knowledge relation, see Susie Linfield, The Cruel Radiance: Photography and Political Violence (Chicago, 2010), 29-30. 
those taken by its officers, as well as between their divergent interpretations. But even here, the focus is on photographs constructing Tibet, as instrumental if not instrumentalizing, rather than on the play of power between participants in a photograph. For Harris, the photographs of John White and other officers created a concept of the "Tibetan sublime," which contributed to a wider discourse of the uniqueness of Tibetan landscape and heritage. ${ }^{21}$ This discourse ideologically severed Tibet from China, allowing it to be "annexed to the imperial project" of an autonomous Tibet under British influence. ${ }^{22}$ Paradoxically, Harris argues, contemporary official Chinese discourse assumes the same stance, recognizing the uniqueness of Tibetan culture only in order to confine it to the past. ${ }^{23}$ While historicizing Tibet as a concept, this approach nevertheless overlooks how the event of photography itself offered Tibetans new opportunities for reconceiving their political relation to one another and to Tibet.

Several alternatives to the instrumental model of photography might be posited. We might think about how a specifically Tibetan understanding of photography developed through the prism of Buddhist concepts of selfhood, appearance, and reality. Linrothe and Harris examine cases where photographs of Tibetan spiritual teachers attained the same ontological value as painted images of deities: as not simply representations of their subject but reifications of its continued living presence. ${ }^{24}$ This approach importantly deconstructs historicist, universalized understandings of photography without requiring that its Tibetan variant existed only in opposition to British imperial ideology. ${ }^{25}$ But provincializing photography does not entail only pluralizing it. It requires us to show how universalized categories of thought are both "inadequate" and "indispensable" to our thinking about photography: to show how we can question singular, universal notions of photography - in this case cameras as instrumental — while keeping open the possibility for its participants to engage with it on similar terms. $^{26}$

We might instead look to the material nature of photography for alternatives to the instrumental model: because photographs are mobile they

21 Clare Harris, The Museum on the Roof of the World: Art, Politics, and the Representation of Tibet (Chicago, 2012), 108-15.

22 Ibid., 82.

23 Ibid., 3-6.

24 Rob Linrothe, "Travel Albums and Revisioning Narratives: A Case Study in the Getty's Fleury 'Cachemire' Album of 1908," in Ali Behdad and Luke Gartlan, eds., Photography's Orientalism: New Essays on Colonial Representation (Los Angeles, 2013), 171-84; Clare Harris, "The Photograph Reincarnate: The Dynamics of Tibetan Relationships with Photography," in Elizabeth Edwards and Janice Hart, eds., Photographs, Objects, Histories: On the Materiality of Images (London, 2004), 139-55.

25 On the struggle between particularizing and generalizing interpretations of photographs, see Julia Adeney Thomas, "The Evidence of Sight," History and Theory 48 (Dec. 2009): 151-68.

26 Dipesh Chakrabarty, Provincializing Europe: Postcolonial Thought and Historical Difference (Princeton, 2008 [2000]), 6, 21-22, 249-55. 
produce different meanings and power relationships in different contexts; because Kodaks were cheap and portable they were easily appropriated and turned against those who would otherwise only take photographs; because photographers never completely control their subjects there is always the potential for noncompliance, for making photographs "negotiations." 27 In all of these alternatives, though, is the notion of the photographer's and the subject's a priori agency and of power as a contestable object brought to the photographic event. ${ }^{28}$ Whether focusing on the mobility of photographs and cameras or the unpredictability of photographic subjects, these arguments nonetheless present power as preceding and enacted during the photographic event. Power is presented as an object imposed and resisted, derived from an agent as the ultimate originating cause and as prior to its relation with another. The outcome-here the understanding of Tibet as a political space-becomes an effect of the power brought to and contested in the photographic event rather than received from it. The upshot is that we find in the event only the power, and the vision of Tibet, that we ascertained an agent as capable of bringing to it in the first place. The event becomes only a time and place in which action occurs, emptied of any political significance itself, and of the potential to produce a new experience of power in which all participants have the capacity to think anew their relation to Tibet.

How might we view photography and its relation to Tibetan political space differently? We need to move beyond a conception of the camera as simply an instrument for smoothly translating cause - what the photographer wants - into effect. We need instead to think of the camera as itself an active element in a chain of agency that also runs the other way: the camera is not just an "intermediary," but a "mediator," in a photographic event the outcome of which is always open. Participants receive agency through interaction with one another and do not merely bring it to the event as a pre-packaged object. ${ }^{29}$ This is what Azoulay describes as a distinction between the "photographed event," the action re-presented by a camera, and the "event of photography," the action brought into being by the actual or potential presence of that

${ }^{27}$ On the circulation of photographs, see Deborah Poole, Vision, Race, and Modernity: A Visual Economy of the Andean Image World (Princeton, 1997), 6-11, 140-41. On appropriation of photography, see Christopher Pinney, "Introduction: "How the Other Half...,", in Christopher Pinney and Nicholas Peterson, eds., Photography's other Histories (Durham, 2003), 1-3; Karen Strassler, Refracted Visions: Popular Photography and National Modernity in Java (Durham, 2010), 4, 19, 23, 147-48; Christopher Pinney, "The Prosthetic Eye: Photography as Cure and Poison," Journal of the Royal Anthropological Institute 14 (2008): 533-46. On negotiation within photography, see Shawn Michelle Smith, Photography on the Color Line: W.E.B. DuBois, Race, and Visual Culture (Durham, 2004), 2.

${ }^{28}$ For a subtle reorientation, see Erik Mueggler, "Bodies Real and Virtual: Joseph Rock and Enrico Caruso in the Sino-Tibetan Borderlands," Comparative Studies in Society and History 53, 1 (2011): 6-37.

29 Bruno Latour, Reassembling the Social: An Introduction to Actor-Network Theory (Oxford, 2005), 58-59. 
camera. ${ }^{30}$ For Azoulay, the event of photography becomes a means by which a new pattern of relations between the photographer and the photographed is established in relation to, but is not derived from, the existing political order. ${ }^{31}$ Through "an act of imagination" by subsequent spectators of the photograph, the potential for a new power relation between the participants in the photographed event can be realized. ${ }^{32}$ Taking the four Chinese soldiers as an example, our spectatorship of the photograph can "suspend" the political conditions for their subordination - a weak Chinese presence in Tibet and an aggressive British one - and activate a new shared "civil political space" in which the Chinese soldiers join their British Indian aggressors, and us as spectators, to stand in relation to a political order that would otherwise only circumscribe them as its subjects. ${ }^{33}$

But what about the Chinese soldiers as themselves participants in the event? Must they wait for future spectators to place them in a new field of action? In the examples that follow, I focus not on spectators activating the event's potential but instead on the ability of its initial participants, especially Tibetans, to themselves grasp the potential to rethink their relation to Tibet. $^{34}$ Thinking with Ricoeur, I see the event of photography as proposing a "hermeneutics of the self": as the receipt of agency, through one's interaction with another, to think differently about - to think outside of - the political conditions in which one finds oneself. In this reading, agency stands "in front of" the event, not behind it, received, in the example above, through the interaction of the Chinese soldiers and their British Indian opposites during the event itself. $^{35}$ But for participants in the event to realize its proposal to think differently about their political status there must be what Badiou terms an "effort."36 It is not a case of them negotiating relations within the conditions of possibility of thought established by the photograph, but rather of them recognizing the photograph as a legislator of those conditions and the potential creator of new ones: they must understand the event as reproducing its action as an interpretable text. This does not mean that participants require an understanding of its material afterlife; action can be narrativized, and thus give meaning to its

30 Azoulay, Civil Imagination, 21, 26-27.

31 Ibid., 5

32 Ibid., 3, 23-25, 44.

33 Ariella Azoulay, The Civil Contract of Photography (New York, 2008), 11-14.

34 Azoulay addresses this potential for participants to challenge the terms under which they are treated as citizens, but this interpretation remains within an understanding of agency as existing prior to the event rather than constituted by, and derived from, the interaction of self and other (ibid., 17-20, 117).

35 Paul Ricoeur, Oneself as Another, Kathleen Blamey, trans. (Chicago, 1992), 16; Olivier Abel, "Paul Ricoeur's Hermeneutics: From Critique to Poetics," in David Kaplan, ed., Reading Ricoeur (Albany, 2008), 190-93.

36 Alain Badiou, with Fabien Tarby, Philosophy and the Event, Louise Burchill, trans. (Cambridge, 2013), 9-10, 48-49. 
participants, without becoming a physical text. But the photograph's unique ability to reproduce the event that created it, of which many Tibetans were aware, increased its participants' potential to convert its proposal for thought into thought itself.

This move performs several tasks. It is a way of showing the significance of photography as a potential rupture in the conditions of possibility within which its participants are able to act and think. ${ }^{37}$ It shows the capacity for all of its participants to realize that potential without our having to choose between the instrumental function of the camera, whether disempowering or emancipatory, or the redemptive function of the spectator. It is especially important for showing the significance of photography as an event in Tibet, one that keeps the political imaginary of Tibet open to all, in the past as much as the present. Rather than being a political object that pre-existed or was constructed through photography, an object that it is our task to reconstruct, Tibet itself becomes an event, proposed through the event of photography. We destabilize not only the closed, zero-sum concept of power as an object and the camera as its instrument, which prevails in much photographic theory, but also the replication of that concept in polemical contests historically reconstructing Tibet's "authentic" status as a territory. ${ }^{38}$ In short, we move from the "excess" of history under which the Tibet of polemics can find itself toward an "unhistorical" Tibet, one contained within, contingent upon, and made indeterminate by the event of photography. ${ }^{39}$ This is a Tibet in which the potential for action and thought is kept open both within versions of its history and despite them, for Tibetans as well as their interlocutors.

\section{"FIXING" TIBET}

For John White, the Tibetan emissary sent to meet the British expedition encamped outside Khampa dzong, a fortress town in southern Tibet, was a strange yet sadly predictable choice. The "abbot" of Trashi Lhünpo monastery, seat of the Panchen Lama, seemed an unlikely candidate to negotiate the withdrawal of a British "trade" expedition composed of five hundred soldiers and support staff. ${ }^{40}$ According to White, the abbot "said he did not know why he had been sent on this work, as his work was purely devotional, and that he knew absolutely nothing of politics." 41 The abbot was to request the expedition

\footnotetext{
37 This focus on the ontological novelty of the event, and its importance for the initial participants, parts company with Azoulay in Civil Imagination, 26.

38 Sperling, China-Tibet Conflict, 4.

39 Nietzsche, "On the Uses and Disadvantages of History," 61-64, 110, 120.

40 Major monasteries were divided into tratsang (colleges) with their own abbots, but no single abbot presided over the whole monastery. Mervyn Goldstein, A History of Modern Tibet, 19131951: The Demise of the Lamaist State (Berkeley, 1989), 26-27.

41 John Claude White, Tibet and Lhasa, 2 vols. (Calcutta, 1908), I, "The Abbot at Kham-pa-Jong."
} 
to return to Giagong, which Tibetans considered to be the frontier, and although Younghusband found him "a charming old gentleman," he repeated the assumption that the abbot's spiritual upbringing made him "innocent-minded" when it came to politics. ${ }^{42}$

The photograph White took of the abbot in late August 1903 reinforced this impression: bathed in light, sat next to a busy table of devotional objects and clutching his $m \bar{a} l \bar{a}$ (rosary), he is a picture of serene detachment (figure 2). The amban's delegate sits to his right, more disconcerted. But though presented as surprising, the choice of the abbot, and the photograph taken of him, fulfilled British assumptions about the state of Tibetan governance and its consequent subservience to China. As British Resident of neighboring Sikkim and second in command to Younghusband, White was well-attuned to official British claims that Tibet's governing theocracy had brought the expedition on itself. ${ }^{43}$ Through its spiritual detachment and "feudal" parasitism over the Tibetan people, with an estimated quarter of males being monks, the monastic hierarchy was routinely represented as an economic deadweight and as incapable of realizing Tibet's "true" status as an independent country. ${ }^{44}$ The aesthetic of White's photograph, as well as its publication after the expedition in the lavish two-volume album Tibet and Lhasa (1905) by Johnston and Hoffman, indicates its replication of this trope. Johnston and Hoffman was a Calcuttabased company that often bought the copyright to officially commissioned photographs, suggesting that the album's primary purpose was as an official justification of the expedition likely gifted to Curzon, a legitimation of Britain's semi-colonial intervention against the shackles of "Lamaism." 45

The concept of Lamaism predated the Younghusband expedition, but during the expedition it assumed a newly pointed aspect. The term derived from the Tibetan word bla ma (lama), used by Tibetans to designate religious laymen, monks, reincarnations, or in fact any teacher deemed worthy of respect. While this manner of describing spiritual exemplars was mostly restricted to Tibetan Buddhism it was by no means its defining feature. But seeking their own distinction, Chinese Buddhists reified the term as lama jiao, "teachings of the lamas," a reductionism not helped by the ninth Panchen Lama's (1883-1937) own decision to preserve Tibetan Buddhism's distinction from Chinese Buddhism by transliterating, rather than translating, the Chinese term for the latter into Tibetan. ${ }^{46}$

42 Francis Younghusband, India and Tibet (London, 1910), 125-27.

43 Harris, Museum on the Roof, 112.

44 Graham Sandberg, Tibet and the Tibetans (London, 1906), 121. Goldstein puts the figure slightly lower, at a maximum of 20 percent of males; History of Modern Tibet, 5.

45 Pamela Deuel Meyer and Kurt Meyer, In the Shadow of the Himalayas: Tibet, Bhutan, Nepal, Sikkim (Ahmedabad, 2005), 9.

46 Tuttle, Faith and Nation, 70-71. 


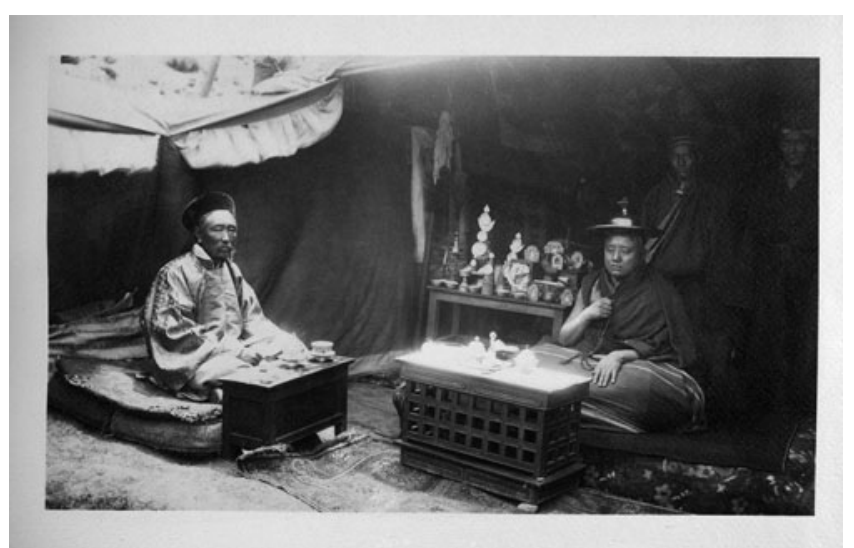

Figure 2 John Claude White, "The Abbot at Kham-pa-Jong." Source: Tibet and Lhasa, 2 vols. (Calcutta, 1908), I, (c) British Library Board, unnumbered, British Library, London.

British Orientalist Laurence Waddell, also the expedition's principal medical officer and official "antiquarian," systematized these distinctions for an English audience with his The Buddhism of Tibet or Lamaism, published in 1894. Through years of ethnographic research while an Indian Medical Service officer in Darjeeling, Waddell concluded that Tibetan Buddhism was a deviant form of the original "pure" Mahayana Buddhism that originated in India. ${ }^{47} \mathrm{He}$ located this deviance in what he believed to be the "invented" divinity of the Dalai Lama and his "false" cycle of reincarnations. ${ }^{48}$ Leaders of the Gelukpa school of Buddhism first assumed the title of Dalai Lama in 1578, before Lozang Gyatso (1617-1682) deposed the king of Tsang (western Tibet) and established dominance of the school over central Tibet in 1642. Contrary to an earlier tradition of representing Gelukpa leaders as reincarnating humans, Lozang Gyatso made an important distinction: he claimed to be the reincarnation of bodhisattva Avalokiteśvara. That is, he occupied a different ontological realm with a different temporality, but elected to remain within the cycle of reincarnation rather than proceed to nirvana. For Waddell, this established a false theological-temporal distinction of Tibetan Buddhism from Mahayana Buddhism, which did not recognize the Dalai Lama's bodhisattva credentials. ${ }^{49}$ The Dalai Lama's divinity ensured Tibetan Buddhism's independence, a useful point for anyone trying to deny Tibet's theological

47 Harris, Museum on the Roof, 44-45.

48 Laurence Waddell, Lhasa and Its Mysteries (London, 1905), 27-30.

49 Laurence Waddell, The Buddhism of Tibet, or Lamaism (London, 1895), 227-31; Kapstein, Tibetans, 135-41; Ardy Verhaegen, The Dalai Lamas: The Institution and Its History (New Delhi, 2002), 12-13; Rebecca French, The Golden Yoke: The Legal Cosmology of Buddhist Tibet (Ithaca, 1995), 69-72. 
incorporation within China, but this independence equally severed it from Buddhism in British India.

Members of the Younghusband expedition seized on Waddell's criticism of "Lamaism" and attached to it an interpretation of Tibet's "failure" to become an independent nation-state with "normal" diplomatic relations. Because temporal and spiritual power was united in the Dalai Lama, a unity established by the accession of the Fifth Dalai Lama in the mid-seventeenth century, the ostensibly empty cyclical time of his reincarnations could also be applied to the history of the Tibetan state and its relation to Tibetan nationality. ${ }^{50}$ For example, Edmund Candler, a Daily Mail correspondent on the expedition, argued that the monastic elite kept Tibet within medieval time through its feudal "spiritual terrorism" of lay "serfs." Lamas, he asserted, rejected relations with neighboring countries for fear that "intercourse with other nations must destroy their influence with the people." $" 51$ Rather than embodying a "modern" state that represented a nation, the monastic elite only perpetuated a medieval one that precluded its realization. ${ }^{52}$ Younghusband made the point explicit in his claim that the monks wanted peace above all things, and, "To obtain it they are ready to sacrifice their national independence." 53 Like the Dalai Lama's "invented" reincarnating divinity, which consigned Tibet to an empty cyclical time, Tibet's theocracy prevented its "natural" historical emergence in linear time as a nation allied to an independent state with international diplomatic relations. The purpose of the expedition could therefore be presented as exposing lamaic "tyranny" so as to enable Tibet to realize its rightful independence within historical time. ${ }^{54}$ For the expedition's Times correspondent Perceval Landon, the British took "the role of Perseus rescuing Andromeda from a monster," a significant analogy given Andromeda's subsequent marriage to her rescuer. ${ }^{55}$ By showing Lamaism for what it ostensibly was and forcing its own version of autonomy on Tibet, Britain could improve its diplomatic ties against the claims of China and Russia, even if marriage was out of the question.

We might feel confident about the role photography played in this story. It might seem, as it did with White's photograph, that expedition members deployed photography to discredit the monastic elite and turn those

\footnotetext{
50 This system of government was expressed in the phrase chösi nyitrel, "religious and political affairs joined together"; Goldstein, History of Modern Tibet, 2.

51 Edmund Candler, The Unveiling of Lhasa (London, 1905), 246, 278.

52 The medieval trope was playfully interpreted by Lieutenant Norman Rybot's Tapisserie de Yatunge, a series of illustrations painted during the expedition between January and April 1904, in the style of the Bayeux Tapestry, which depicted the British as picaresque Normans entering Tibet. Mg N07/09K, Royal Geographical Society, London. See also Henry Newman, "Monks of the Middle Ages," Sphere, 22 Oct. 1904: 78.

53 Francis Younghusband, "Lamaism in Tibet," Sociological Review 4, 2 (1911): 98-109, 98.

54 Candler, Unveiling of Lhasa, 246; Lopez, Prisoners of Shangri-La, 43.

55 Landon, Lhasa, I, 302.
} 
photographed into subalterns of a British political imaginary. But this interpretation remains constrained within a notion of power as an object, which is only brought to the event of photography. It is an interpretation that replicates the British photographer's own notion that they "took" the photograph, and Tibetans were only subjects of the photographic event rather than actants through it, even though the photographer might at the same time believe that the camera's objectivity meant that it spoke for itself. Here we hit a problem: if we find behind the illusory objectivity of photography the power that the photographer brings to the event, then how did the photographer come to "possess" power in the first place, power that wholly precedes the circumstances of its enactment? We are diverted from the photograph itself, trapped within a circle of perpetually re-designating that which stands behind it. ${ }^{56}$

We can unpack these dilemmas through Landon's photographs of monks from a monastery close to Gyantse, a town where the route from Sikkim divides between Shigatse in the northwest and Lhasa in the northeast. While the expedition was stationed at Gyantse in April 1904, Landon rode out with Captain Frederick O'Connor, the expedition's translator and intelligence officer, to explore the valley. Their guide brought them to a small monastery where the monks, to Landon's fascinated horror, followed a practice of sealing themselves in mountain cells closed to the outside world except for a small food hatch. Although this was presented as voluntary, Landon was skeptical: "The grip of the lamas is omnipotent and practically none refuse." 57 Photography could be seen here as an implicit way of redeeming, through showing the conditions of their oppression, the monks Landon believed were "condemned" to incarceration. ${ }^{58}$ By photographing a cell entrance (figure 3 ) and then young monks set for self-imprisonment in the near-future (figure 4) a dialectic of visibility and invisibility, of freedom and imprisonment, was potentially created, employing the dialectic of time within the photograph. The monks were visible in the photograph, but they also were always-already invisible because the photograph made present that which was already absent. In the vein of Barthes, the monks were free, and yet already imprisoned, apparently exposing the lamaic oppression that blocked Tibet's path towards becoming a nation-state. ${ }^{59}$

\footnotetext{
56 Charles Taylor, "Paul Ricoeur's Philosophical Anthropology," Golden Jubilee Lecture at the Centre for the Study of Developing Societies, Delhi, 25 Nov. 2013, www.csds.in/events/ charles-taylor-paul-ricoeur-0 (accessed 22 Feb. 2015).

57 Landon, Lhasa, I, 226.

58 Ibid., 227. The subversive imperative behind Landon's photographs is shown by the contrasting description of immured monks given by Swedish explorer Sven Hedin, who found immurement to be the monk's choice and an instance of "fortitude" and "patience" beyond conception. Sven Hedin, Trans-Himalaya: Discoveries and Adventures in Tibet, 3 vols. (London, 1909-1913), II, 5.

59 Roland Barthes, Camera Lucida: Reflections on Photography, Richard Howard, trans. (London, 2000), 95-96.
} 


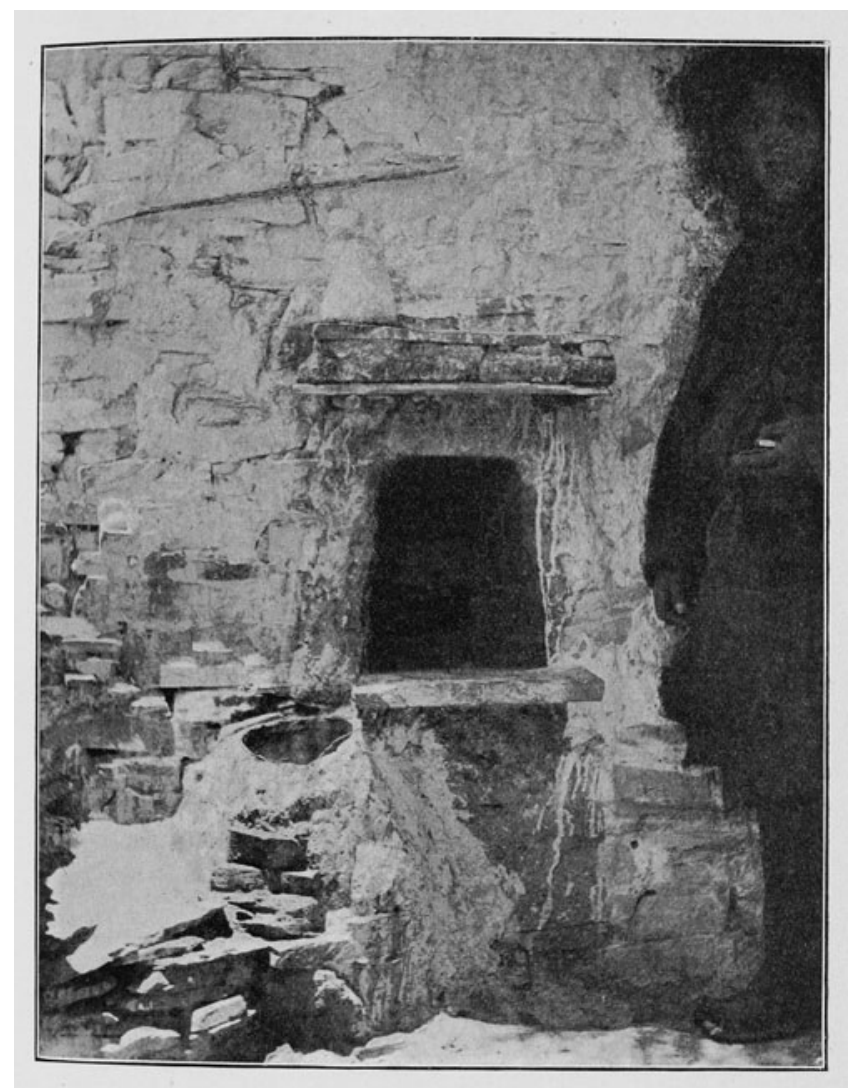

Figure 3 Perceval Landon, "Stone wicket of underground cell." Source: Lhasa: An Account of the Country and People of Central Tibet and of the Progress of the Mission Sent there by the English Government in the Year 1903-04, 2 vols. (London, 1905), I, facing 222, Bodleian Library, University of Oxford, 24629 d.1, 2.

Photographs like these might also be read against those that appear to show British benevolence toward Tibetans. Photographs of Tibetans being treated in a British field hospital or receiving alms from an Indian "chuprassi" (attendant) (figure 5) could be seen as representing, and producing through that representation, a Tibetan subalternity based on the contrast between lamaic oppression and British benevolence. ${ }^{60}$ Far from showing British mercy, they

60 Lieutenant Frederick Bailey's photographs of wounded Tibetans were reprinted in Candler's Unveiling of Lhasa, facing page 130. For the photographs outside Candler's retrospective triumphalism, see Bailey's personal album: Frederick Bailey, photograph album, Tibet 1903-04, British Library, Photo/1083/13 (135-37). 


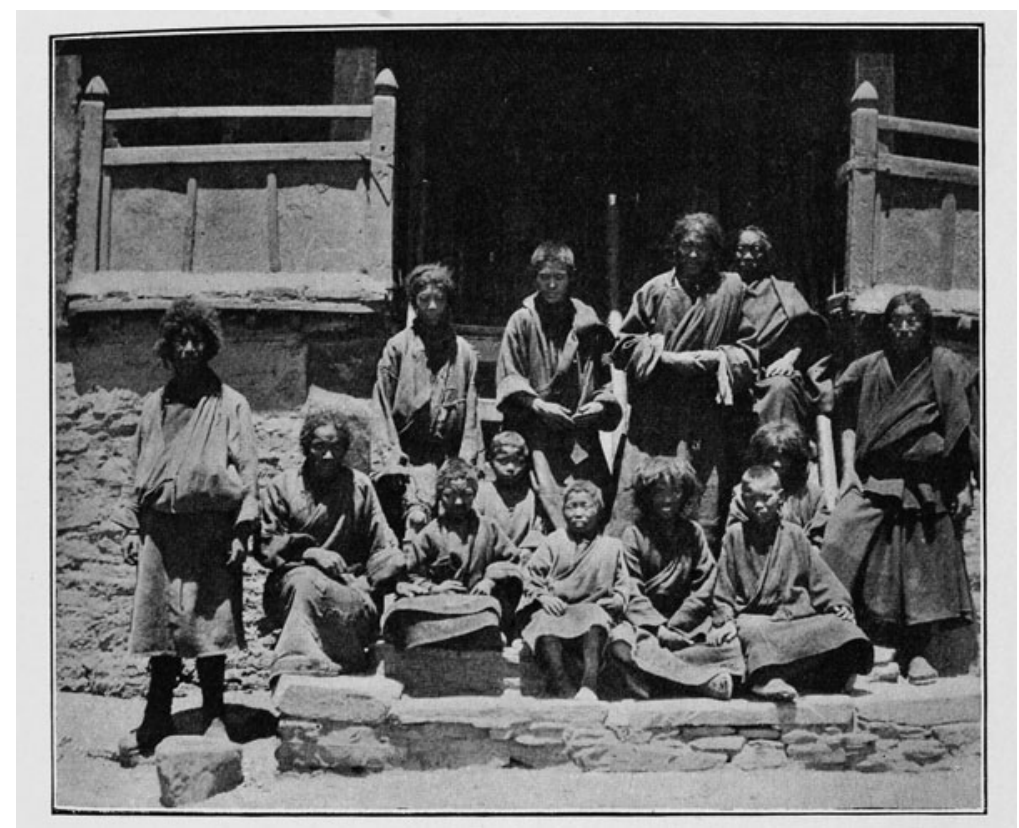

FiguRe 4 Perceval Landon, "Waiting for immurement." Source: Lhasa: An Account of the Country and People of Central Tibet and of the Progress of the Mission Sent there by the English Government in the Year 1903-04, 2 vols. (London, 1905), I, facing 227, Bodleian Library, University of Oxford, 24629 d.1, 2.

could be considered as intrinsically violent because they were predicated on a disparaging contrast with what were perceived to be Tibetan values. Landon wrote, "Mercy to prisoners is not a characteristic of the Oriental," and he said most of the prisoners instead expected a "coup de grâce." common interpretation, photographs, especially photographs of mercy, are epistemologically violent because they convert their subjects into tools of whoever holds the camera; it is unimportant whether the subject's subordination to the photographer aligns with their own purposes because that subordination is underwritten by our conventional, and ahistorical, assumption that the photographer has sole ownership rights over the photograph both during and after its production. ${ }^{62}$

Yet these photographs betray loose ends that call such a reading into question. At one level we could point to inaccuracies in the claims on which they

61 Landon, Lhasa, I, 157.

62 Ariella Azoulay, The Civil Contract of Photography (New York, 2008), 98-99. 


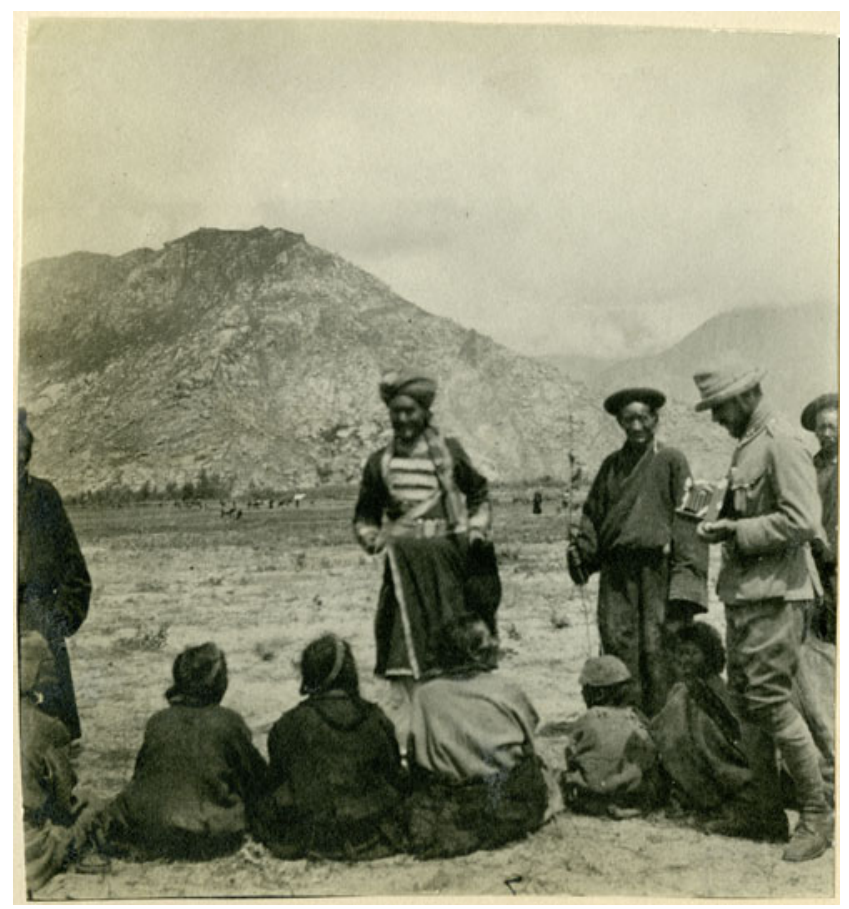

FiguRE 5 G. I. Davys, "The chuprassi distributing the tunkhas to the poor at Lhasa. Note the bag of money in the chuprassi's left hand." Source: unpublished photograph album, F005/016011, Royal Geographical Society, London.

were based. Landon's photographs, for example, derived some of their effect from the claim that the monks were incarcerated for life, but in reality it was almost certainly for a couple of years at most, and then only for a select few monks. In this light, the photographed event is not one of subaltern Tibetans unable to constitute themselves as agents under lamaic hegemony: Landon's claim remained unknown and in any case unimportant to monks who knew better, even if this was not the case for contemporary British spectators of his photographs. More importantly, at another level Gerard Davys's photograph of almsgiving shows that the event of photography itself does not constitute those Tibetans as subalterns within a British imaginary but rather reveals its inability to do so. The photograph records not only the apparent benevolent distribution of "tunkhas" (trangka, the basic unit of Tibetan currency), but also the act of recording it: it includes another photographer within the frame as both a photographer of and subject of the event. By doing so, I want to suggest, the photograph reveals the indeterminable distribution of power during the event of photography itself. 
It is tempting to persist with an interpretation of Davys's photograph as instrumental. One might argue that by accidentally including another photographer, by representing the practice of representation, his photograph makes it obvious that photography of almsgiving turns its subjects into instruments of a British imaginary, thus explaining why the photograph went unpublished in expedition accounts. ${ }^{63}$ But this argument depends on a generic conception of property that had little relation to early twentieth-century photography. Far from photographs being unambiguously the property of those who "took" them, products of undivided authorship, in 1903 their ownership was legally re-designated at different moments in their existence, shifting the grounds on which their instrumentality might be based. The Fine Arts Copyright Act (1862) granted copyright to the "author" of any photograph, provided they register it at Stationers' Hall. However, if the photograph was commissioned, for example by the press, the commissioning agent owned the copyright, even if they could not register themselves as the photograph's author. If the photograph had not been commissioned, and no agreement had been made between the photograph's author and its purchaser before it changed hands, then all copyright was lost. ${ }^{64}$

Even with these provisos, the notion of who held the copyright of something that was intrinsically a copy remained unclear. Judges disagreed over whether the author was the person who arranged the photograph and pressed the button, or instead was the "mastermind" behind it. ${ }^{65}$ Newspapers routinely failed to attribute authorship to photographs so as to make it appear that their own staff photographers had taken them, and piracy remained common. ${ }^{66}$ Press agencies like the Illustrated Press Bureau required photographers who deposited photographs with them to surrender control over the management of their own copyright. ${ }^{67}$ All of this means that the expedition's photographs, "taken" as they were by men with varied arrangements (or no arrangements) with the press and the government, cannot be reduced to a single notion of ownership that assumes a photograph is the property and tool of the photographer. The argument that Davys's photograph accidentally revealed the instrumentalizing purpose of its author and owner, and for this reason was not published, is therefore unsupportable. Moreover, if Davys did legally have sole authorial control over the photograph as its creator and owner, then what would

\footnotetext{
63 Ibid., 138-42. For a similar argument, see James Hevia, "The Photography Complex: Exposing Boxer-Era China (1900-1901), Making Civilization," in Rosalind Morris, ed., Photographies East: The Camera and Its Histories in East and Southeast Asia (Durham, 2009), 112.

${ }^{64}$ Walter Arthur Copinger, The Law of Copyright, [...], J. M. Easton, ed., 4th ed. (London, 1904), 366-70; Thomas Edward Scrutton, The Law of Copyright, 4th ed. (London, 1903), 179-92.

65 Lord Justice Cotton, in Nottage v. Jackson (1883), cited in Copinger, Law of Copyright, 371.

${ }^{6}$ Gary Beegan, The Mass Image: A Social History of Photomechanical Reproduction in Victorian London (Basingstoke, 2008), 166-68 n32.

${ }^{67}$ Henry Snowden Ward and Catherine Weed Barnes Ward, Photography for the Press: By the Editors of "The Photogram" (London, 1901), 20; Beegan, Mass Image, 171.
} 
publishing it - a photograph of almsgiving, after all—show the British public that it did not already know?

Perhaps it was simply a bad photograph. But despite the expedition's hundreds of photographs and the fevered public interest in its activities, no newspaper or retrospective account published a photograph of photography. This is not because these photographs show photography's instrumentality but because they show its weakness. They show an intrinsic indeterminacy to the relations in the event of photography, an event that neither simply articulates the inequalities which cause subject and photographer to be arranged in a particular way, nor becomes itself a tool through which those inequalities can be created and over which total control can be achieved. ${ }^{68}$ As Azoulay notes, the assumption that photographs are the sole product and property of the photographer ignores the way that photography, as itself an event, brings into being "a form of relation" that can never be closed: photography opens a "political space," in Arendtian terms, which is neither reducible to nor finished by the photographer's intention. ${ }^{69}$ At the same time as the photograph of almsgiving is the product of Davys's decisions about composition and timing, by recording another photographer it reveals that such decisions depend on decisions of others. More precisely, it reveals the constitution of his decisions through those of others, from the stray glance of the seated Tibetan to the stoical hunch of the child beside her.

To think otherwise, to conceive photographs as the undivided product and property of photographers, risks continuing rather than critiquing the expedition's violence against Tibetans. It risks replicating the assumptions that expedition members held about property that underpinned the way they legitimated their looting. Contrary to its prohibition under Article 48 of the 1899 Hague Convention, looting was common among expedition members. ${ }^{70}$ It ranged from scavenging curios on the battlefield at Guru, where on 31 March 1904 a Tibetan contingent faced two Maxim machine guns, to systematically removing high-value artefacts like thangka (paintings) from Gyantse dzong (fortress) after it succumbed to the expedition in April. The number and spiritual significance of artefacts subsequently sold or gifted to museums indicates that, until Younghusband finally enforced the prohibition when the expedition reached Lhasa that August, not all were legitimately acquired. ${ }^{71}$ The rank-and-file justified their looting by the assumption that by offering resistance Tibetans forfeited their "property rights." 72 According to this notion of property, possession always-already guaranteed dispossession in the Tibetan encounter with the expedition. Either Tibetans offered no resistance to the acquisition

68 Azoulay, Civil Imagination, 24-25, 17.

69 Ibid., 52-53; Azoulay, Civil Contract, 85.

70 Tim Myatt, "Looting Tibet: Conflicting Narratives and Representations of Tibetan Material Culture from the 1904 British Mission to Tibet," Inner Asia 14, 1 (2012): 61-97, 65.

71 Harris, Museum on the Roof, 58-70.

72 Ibid., 63. 
of property or their resistance deprived them of any rights to it: their agency was only possible under the terms of a British understanding of property which automatically denied it.

The same logic is repeated in an understanding of photographs as always-already the photographer's property and of their subjects as intrinsically instrumentalized. In both perspectives Tibetans are dispossessed of propertyownership of their possessions and of the photograph - by the very fact of their possession. An officer's photograph of monks "running away from the camera" in Gyantse monastery shortly after the town was occupied by the British might then be taken as doubly dispossessing: first through the photograph, and second through the looting accompanying it. ${ }^{73}$ However, a photograph taken by Lieutenant Frederick Bailey at Nagartse about a month later suggests a different interpretation (figure 6). On the same day as the photograph took place, 19 July 1904, a Tibetan deputation consisting of a shape, the chigyab khembo (chief monk official), and the Ta Lama (a lower-ranking monk official) met with Younghusband to persuade him to turn back for treaty negotiations at Gyantse rather than pushing on to Lhasa. The deputation vigorously argued that, in Younghusband's words, "By the mere fact of our going to Lhasa we should spoil their religion, as no men of other religions were allowed in Lhasa."74 The photograph shows that it was not only religion that Tibetans at Nagartse feared for, but also its sacred artefacts. A line of Tibetans stands in the glaring June sun holding a petition against looting " 25 feet long," an attempt to avert a repetition of Gyantse's fate as it became clear that Younghusband brooked no religious reasoning. ${ }^{75}$ The petition shows Tibetans rejecting the concept of property outlined above not only in the photograph but also through it. They reject the assumption that they are a priori dispossessed, subjects of British looting, but also the idea that they can only bring their prior disempowerment to the photographed event, or become its instrument when it occurs. It is not that they turn the photograph's objectifying "gaze" against the photographer: this "speech" would still only be possible through the photographic discourse that constituted them as subaltern. It is rather that the petition acts as a mirror reflecting back to the photographer the Tibetans' role in constituting his action during the event and at the same time constituting their own action through this interaction. The photograph might derive pathos from the fact that the petition's Tibetan writing made it indecipherable to all but a few on the expedition, ${ }^{76}$ but this does not prevent it from showing

\footnotetext{
73 It has unfortunately been impossible to trace the copyright holder of this image to obtain permission to reproduce it. Anon., "Monks in Gyantse Monastery running away from the camera," unpublished photograph album owned by Charles Bell, 50.31.153, 16, Liverpool World Museum, Liverpool.

74 Younghusband, India and Tibet, 228.

75 Also reproduced in Harris, Museum on the Roof, 67.

76 I am grateful to Clare Harris for mentioning this point to me.
} 


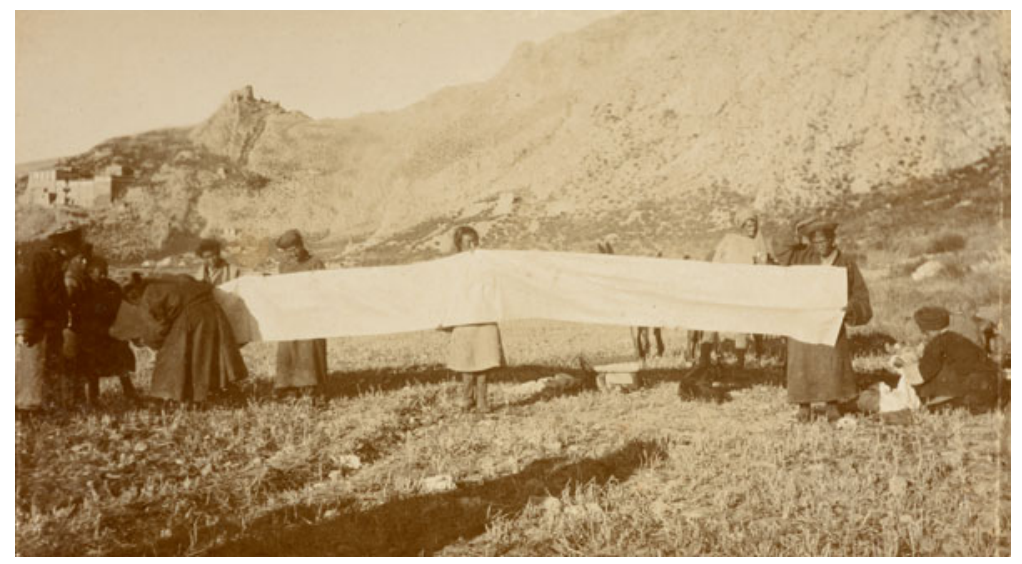

Figure 6 Frederick Bailey, "Petition against looting presented 2 Col. Younghusband at Nagantse 25 feet long." Source: unpublished photograph album, Tibet 1903-4, (c) British Library Board, photo/1083/11 (137), British Library, London.

itself to be an event in which all participants constitute themselves as capable of acting through their relations with another.

Because these relations are never closed, the event of photography could be seen as extending beyond the frame of the photographed event to incorporate subsequent spectators of the photograph, including ourselves. The photographs could be imagined as a "form of address" by which the Tibetans petition us to conceive of them outside of the conditions of inequality, and outside of the British imaginary of Tibet, occasioning their protest. ${ }^{77}$ But what about their addressing others within the photographed event? How did this address, brought into being through photography, create the potential for Tibetans themselves to imagine a different political relation to Tibet than the one in which they found themselves?

\section{ALTERNATIVE IMAGINARIES}

Maybe all it took was a Tibetan on the other side of the camera. Tibetan photography certainly predated, even if it could not equal in scale, that of the Younghusband expedition, and it is possible that it occurred during the expedition itself. During the pundit Sarat Chandra Das's covert trip to Tibet in 1881, the chief minister (Sengchen Lama) of Trashi Lhünpo, the principal monastery located southwest of Lhasa on the route to Kathmandu, showed him a work he was writing on photography, based on notes Das had supplied in 1879 from

77 Azoulay, Civil Imagination, 44. 
Tassinder's Manual of Photography. ${ }^{78}$ After returning to India, Das sent the minister a camera. ${ }^{79}$ A few years later, following his expedition to the SikkimTibet frontier in 1884, the secretary to Governor of Bengal Colman Macaulay received a request from the minister for "some apparatus for rapid photography." ${ }^{80}$ It is unclear, though, how much photography subsequently became established at Trashi Lhünpo, a monastery of around 3,800 initiated monks, or whether it overlapped with the Younghusband expedition, which bypassed the monastery. ${ }^{81}$ We do know that some Tibetans were taking photographs shortly after the expedition; when Swedish explorer Sven Hedin visited Trashi Lhünpo in 1907 he met a monk who took his portrait for the Panchen Lama and developed the plates in his own dark room. The monk had learned photography in India during a trip there with the Panchen Lama in $1906 .{ }^{82}$ The Panchen Lama himself also seems to have taken a camera on the trip since he gifted several of his photographs to Frederick Bailey, by then the newly established British trade agent in Gyantse. ${ }^{83}$ But none of this points to Tibetan photography during the Younghusband expedition itself.

There were other ways that Tibetans could be in the event of photography without being subject to it. Alongside Sidkeong Namgyal, the kumar (heir to the throne) of Sikkim, and Ugyen Wangchuk, penlop (regional governor) of Tongsa and de facto ruler of Bhutan, Tibetans served the expedition as aides and translators. ${ }^{84}$ Captain Frederick O'Connor, the expedition's translator and intelligence officer, was accompanied by a Tibetan monk named "Shabdrung Lama" (Sherab Gyatso; a shabdung is an attendant). Gyatso had been attendant to the Sengchen Lama, but fled Tibet after the latter was executed for harboring Sarat Chandra Das between 1881 and 1882, a violation of the official ban on "foreign" visitors to Tibet. ${ }^{85}$ In Darjeeling, Gyatso was O'Connor's teacher in all affairs Tibetan, and during the expedition he may have arranged photographs with Tibetans. ${ }^{86}$ Evidence for this is scarce, as we would expect, but it seems likely given common practice on British shikars (hunting expeditions) at around that time. ${ }^{87}$

78 Sarat Chandra Das, Journey to Lhasa and Central Tibet (London, 1902), 80.

79 Lamb, British India and Tibet, 122.

${ }^{80}$ Colman Macaulay, Report on a Mission to Sikkim and the Tibetan Frontier, with a Memorandum on Our Relations with Tibet (1885), Royal Commonwealth Society Library, Cambridge, GBR/ 0115/Y302592A, 61.

81 Sandberg, Tibet and the Tibetans, 113.

82 Hedin, Trans-Himalaya, I, 364-65.

83 Frederick Bailey, photograph album, Tibet 1903-04, British Library, Photo/1083/17 (218-34).

84 See Sidkeong Namgyal's role in Frederick Bailey's letter to his father, 12 July 1903, British Library, MSS Eur F157/163.

85 Alex McKay, "The British Invasion of Tibet, 1903-04," Inner Asia, 14, 1 (2012): 5-25, 7.

${ }^{86}$ Frederick O'Connor, On the Frontier and Beyond: A Record of Thirty Years' Service (London, 1931), 30-31.

87 "The Roads into Tibet," Black and White, 5 Dec. 1903: 828. Waters also notes the mediating role of "a Sikkimese police sub-officer who could talk the lingo"; Robert Waters, "Notes of a Diary 
But even if Tibetans took or choreographed photographs during the expedition, attaching importance to this keeps us within a paradigm of photography as a contest of preformed will merely implemented by the camera. This is not to say that we should wholly reject the model of the subject as agent. ${ }^{88}$ It is rather that we should adopt a version of action as always-already an involvement in the world, not something entirely separable from and brought to it. ${ }^{89}$ The self should not be conceived as either a priori or illusory, but instead as always oriented toward another, through action, within the world: the self is an ongoing "interaction" with another unfolding over time, an interaction that because of its temporal nature can be narrativized. ${ }^{90}$ It is not simply that the self is an element within a narrative of action, but that it is narrativized by it: the self acquires a "narrative identity" through its interaction with another. ${ }^{91}$ For Ricoeur, this narrative identity is something that agents stand "in relation to"; it is a text that they receive meaning from, and through which they constitute themselves as capable of acting. ${ }^{92}$ In this understanding, the self's relation with another is an engagement that analogically presents itself to the self as a text to be interpreted. It is through this interpretation that the self recognizes its ineluctable relation with another as the condition for its responsibility, in the senses of being both able to respond to another and morally "accountable." 93 In short, narrative identity is the beginning of a new ethics of the self that runs like a thread through the rethinking of power in photography.

We can draw out the implications of this approach through a photograph Lieutenant Gerard Davys took just after the expedition had entered Tibet (figure 7), at Phari (Pagri), a small town southwest of Mount Jomolhari in the wedge of land dividing Bhutan and Sikkim. According to Davys, the women in this photograph "have their hands before their faces to avoid the evil eye," apparently showing their fear of photography. ${ }^{94}$ And yet, the man does not shield his face, and strangely, seems unafraid. The reason for this, I suggest, is that he arranged the event but was captured in the photograph itself. Rather than being afraid of the evil eye - a ubiquitous trope that contemporary British photographers applied throughout East Asia and South Asia-Davys may have asked these

Kept by Robert Sidney Waters, July, August, and September, thro' Sikkim and Thibet," National Army Museum, 1972-01-41-2, 4 Sept. 1903.

${ }^{88}$ Paul Ricoeur, "The Problem of the Will and Philosophical Discourse," in James M. Edie,

Francis H. Parker, and Calvin O. Schrag, eds., Patterns of the Life-World: Essays in Honor of John Wild (Evanston, 1970), 273-89; Ricoeur, Oneself as Another, 4-16.

89 David M. Kaplan, Ricoeur's Critical Theory (Albany, 2003), 82-83.

90 Ricoeur, Oneself as Another, 154-57.

91 Ibid., 143.

92 Kaplan, Ricoeur's Critical Theory, 83.

93 Ricoeur, Oneself as Another, 157.

94 Gerard Davys album, Royal Geographical Society, F005/015850. 


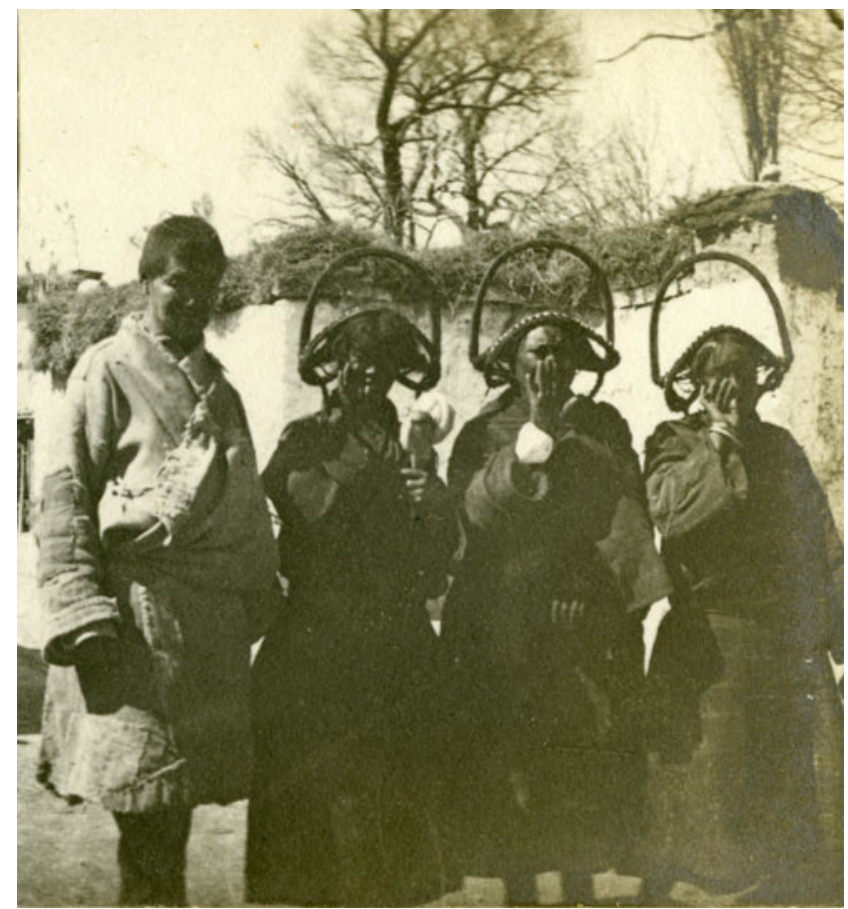

FIgURE 7 G. I. Davys, "Women of Phari. Note the curious head dress. They have their hands before their faces to avoid the evil eye." Source: unpublished photograph album, F005/ 015850, Royal Geographical Society, London.

women to pose in order to fulfil his expectations about Tibetan reactions to photography, thus reifying his modernity in contrast. ${ }^{95}$ The photograph did not just attempt to circumscribe its subjects' action during the event by requiring the women to pose, but also to deny the grounds on which that action was possible. The photograph imputed to these Tibetans the condition of being only objects of another's attention rather than also subjects of, and respondents to, that attention. ${ }^{96}$

This is a crucial denial. It precludes a "reversibility" at the heart of the relation between self and other in the event of photography, a reversibility that this photograph in fact shows. In one respect, the photograph's imputation of an object status on its Tibetan subjects is a condition for all selves in their

95 Rosalind C. Morris, "Photographies East: The Camera and Its Histories in East and Southeast Asia," in Rosalind Morris, ed., Photographies East: The Camera and Its Histories in East and Southeast Asia (Durham, 2009), 1-2.

96 Kaplan, Ricoeur's Critical Theory, 95. 
experience of the world. Unless the self can also conceive of itself as anotherto itself and to others - how can it overcome the paradox that it is both a point of perception and "a body among bodies"?" Their consent to be objects of Davys's expectations, through being purported objects of the "evil eye," shows the women in his photograph fulfilling this condition of selfhood. But this is only half the story. The reverse of this object status, the ability to respond as a subject, is exposed by the man's failure to be "afraid," a failure that fulfils another condition of selfhood that the photograph seeks to deny. If the self must think of itself as another in order to be at the same time a body among other bodies, then it must also think of others as selves in order to be capable of responding to them. The women's relation to Davys is not one of irreducible difference, as the photograph would have it. They are capable of responding because, in asking them to pose, Davys assumes that they are able to respond, and that he is able to understand that response. The women are capable of responding because they have been constituted as speakers, by another who is, like them, a speaker, and who assumes that they can listen and speak. ${ }^{98}$ What the photograph tries to deny, and reveals through that denial, is the constitution of the self as an agent through the voice of another, a constitution intrinsic to every event of photography. By failing to pose, the man shows himself - and the women next to him-as responsible subjects, constituted through the call of another that is recognized as a self.

On its own this might do little to explain how Tibetans could, through photography, think differently of their relation to Tibet. It would be a stretch to see these women, probably paid to pose, as thinking outside the conditions of inequality structuring the event. But when we think about their action in terms of the unique reproductive quality of photography, then the photograph's potential to propose new ways of thinking becomes apparent. Central to this is Ricoeur's understanding of action as a continuous involvement in the world: an agent is always subject to the action they initiate, rather than action being only subject to an agent. An agent only comes to understand the world through its active involvement in it, an involvement that opens up a space of meaning that the agent interprets. ${ }^{99}$ As I explained earlier, the self's responsibility comes through its ongoing relation with another, the meaning of which comes after the fact. Action might then be seen as re-presenting itself as a

97 Ibid., 93-94.

98 Ibid., 93-95.

99 Taylor, "Paul Ricoeur's Philosophical Anthropology." This understanding of the involved nature of action builds on Ricoeur's linkage between narrative as the mimesis of action and "within-time-ness" elaborated in Heidegger's Being and Time. Paul Ricoeur, Time and Narrative: Volume I, Kathleen Mclaughlin and David Pellauer, trans., 3 vols. (Chicago, 1984), I, 60-63. 
narrative text to be interpreted by an agent that brings it into being. ${ }^{100}$ Through this interpretation, the agent comes to interpret himself or herself, to "receive an enlarged self from the apprehension of proposed worlds."101

Ricoeur of course means this metaphorically. But photography, distinct from all other visual media, might be regarded as the exemplar of this understanding of action. Putting aside all of the decisions that the photographer makes about lighting, exposure, framing, and so on, a photograph always indexically reproduces the action bringing it into being. Photography is a form of action that chemically reproduces itself as a text, a text that becomes available for interpretation and, correspondingly, its participants' selfinterpretation. In other words, all those involved in bringing about a photograph become subject to their own action during the event. How does this happen? A single photograph, as only a snapshot of time, is not a narrative. But the self that the photograph re-presents is a narrative. It derives meaning and responsibility only through remaining accountable to another over time. ${ }^{102}$ A photograph therefore does not provide a narrative but re-presents the narrative of the self to the self as an interpretable text. In doing so, it enables the self, those participating in the event of photography, to interpret its relation to the other that constitutes it as responsible. ${ }^{103}$ It enables the Tibetans photographed to recognize themselves as both responsible subjects in the action of the photograph and as subject to the action re-presented as a text. The photograph changes from being only a field of relations within which its participants act, to being also recognized by them as a legislator of those relations and therefore as able to legislate new ones. Through this double-recognition - of responsibility in the photograph and responsibility as interpreters of the photograph-the Tibetans involved become able to imagine new relations to their British interlocutors during the event and to the political imaginary of Tibet that the event establishes. The photograph, in short, becomes a proposal for thought.

Whether or not this proposal is grasped is not conditional on participants in the event understanding its technical reproduction. The artificial orchestration of relations between participants is enough for their action to be

100 Paul Ricoeur, "The Hermeneutical Function of Distanciation," in Hermeneutics and the Human Sciences: Essays on Language, Action, and Interpretation, John P. Thompson, trans. (Cambridge, 1981), 139-42.

101 Paul Ricoeur, "What Is a Text? Explanation and Understanding," 158; and "Appropriation," 182-83; both in Hermeneutics and the Human Sciences: Essays on Language, Action, and Interpretation, John P. Thompson, trans. (Cambridge, 1981).

102 Kaplan, Ricoeur's Critical Theory, 89.

103 A photograph, like every text, moves from an ostensive to a non-ostensive reference from its utterance. It creates a "world" that exceeds its original sense and fuses with the world in which it is received. It is because of the circular referentiality between the world of the text and that of its reader, because a text, like the action it re-presents, is always within the world and time, that it can "bear on" the world, that participants of photographs, confronted with their action as text, become subject to that action. Ricoeur, Time and Narrative, I, 77-79. 
re-presented to them as a text reflecting their coexistence "within-time." But a photographic event's indexical reproduction of itself makes this re-presentation uniquely tangible to its participants, increasing their potential to recognize themselves as responsible subjects in the photograph, and as subject to the photograph. Exactly for this reason, many British photographers denied that Tibetans understood what happened once the shutter had clicked. According to John White, the Tibetans he encountered near Drepung, a major Gelukpa monastery of around ten thousand monks located just outside Lhasa, found the camera "an unfailing source of mystification": "they did not often recognise the reversed picture as that of the scene in front of the lens. It was for them merely a beautiful pattern of varying colours seen in a singularly effective manner."104 Others believed the ostensible credulity of Tibetans was expressed as terror. Below a remarkable photograph of bound Tibetan prisoners captured by the mounted infantry, Frederick Bailey wrote, "The man on the left thought the camera was a pistol, hence his face" (figure 8). ${ }^{105}$ However much this photograph moves us, though, however much it seems to evidence dispossession in its rawest form, the seized weapons flung at the feet of a distressed prisoner now photographed, we must not repeat Bailey's assumption that this was the case. We must not legitimate the role he took as sole claimant to the event through assuming the Tibetan's ignorance of the end result. Other interpretations of Tibetan reactions to photography suggest that other photographers did not always assume the ignorance that Bailey did. While the expedition was in the Chumbi Valley, gateway between Tibet and Sikkim via the Jelap La (Pass), Perceval Landon photographed a woman whom he called "Lady Dordém." He had wanted to photograph her at her doorway, but owing to her "aristocratic" status, Landon claimed, she had insisted on being photographed inside, "seated on a raised platform" with her maid at her shoulder. Landon did not want the maid in the photograph, calling her "dirty," "[b]ut Lady Dordém was firm; she had three husbands in the room at the time, but she would not be taken without a chaperon. She ... very properly argued that no one who saw the picture could know that her natural protectors were at the photographer's elbow." 106 But even here we can only know that Landon, who clearly projected uncompromising notions of class and gender onto Tibetan society, believed that Dordém was aware of the event's afterlife. We are still left wondering how much she really knew about the event's potential to exceed itself as an interpretable text.

However, this does not mean we have to stop at wonder for all expedition photographs. By retracing the global circulation of photographs during the expedition, we find clues regarding how much Tibetans were aware that their

104 Landon, Lhasa, II, notes 250-53.

105 Frederick Bailey, photograph album, Tibet 1903-04, British Library, Photo/1083/11 (82).

106 Landon, Lhasa, I, 365. 


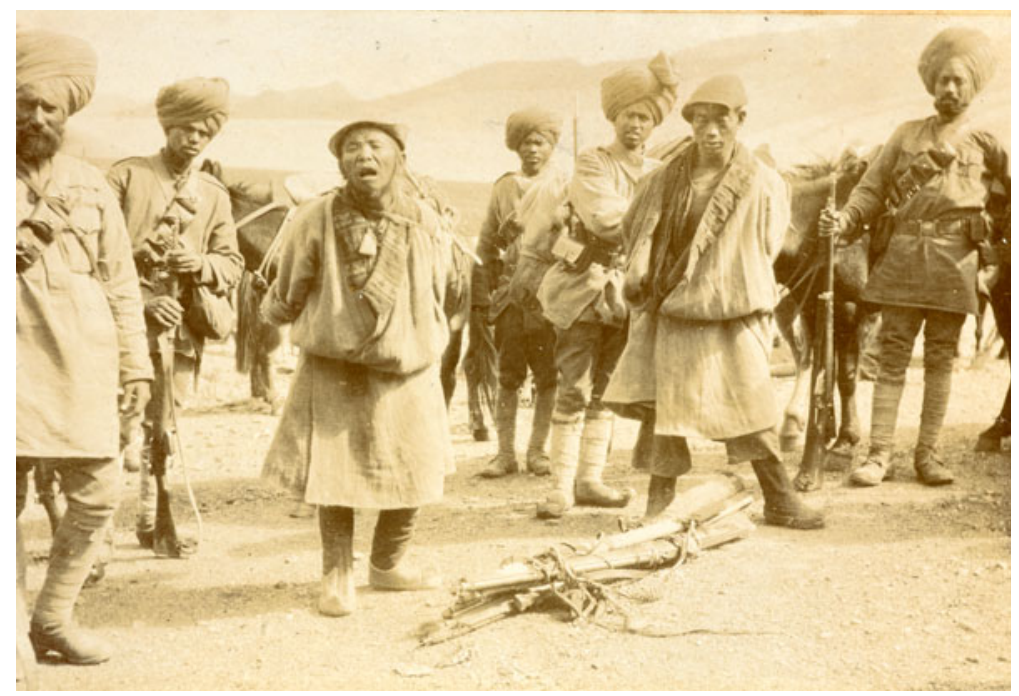

FiguRE 8 Frederick Bailey, "M. I. with Tibetan prisoners. The man on the left thought the camera was a pistol, hence his face." Source: unpublished photograph album, Tibet 1903-4, (c) British Library Board, photo/1083/11 (83), British Library, London.

actions could be re-presented and subsequently interpreted. This circulation was possible because it was not just the Pocket Kodaks expedition members wielded that were lightweight; so too was their celluloid rollfilm, introduced in 1888. In contrast to the bulky glass plates hauled on previous expeditions to the Tibetan frontier, the negatives used on the Younghusband expedition were comparatively easy to order, carry and, once exposed, dispatch back across the Himalayas. ${ }^{107}$ As the expedition advanced on Lhasa, Frederick Bailey ordered films from Calcutta to Tibet and then returned completed rolls for developing in Darjeeling, Calcutta, or Pindi. ${ }^{108}$ In a letter written to his father on 17 November 1903, he explained that the developer would send a print of each negative back to the expedition in Tibet and then the developed films on to his father in Britain. ${ }^{109}$ Bailey even requested that his parents

107 John Edgar, Report on a Visit to Sikhim and the Thibetan Frontier: in October, November, and December, 1873 (New Delhi, 1874 [1969]), 55; Macaulay, Report on a Mission, 31, 49. Some photographers persisted with glass-plate cameras even after rollfilm was introduced: Arnold Landor, Tibet and Nepal (London, 1905), 74.

108 Frederick Bailey, letters, 6 July and 17 July 1903, British Library, MSS Eur F157/163; letters, 20 Jan., 24 Jan., 3 Feb., and 1 Apr. 1904, British Library, MSS Eur F157/164. See photograph of "The Mail Bags of the British Mission on Their Way South to India," "With the British Mission in Tibet," Sphere, 1 Oct. 1904: 15.

109 Frederick Bailey, letter to father, 17 Nov. 1903, British Library, MSS Eur F157/163. See also letters of 24 July and 26 Aug. 1903, British Library, MSS Eur F157/163. 
send additional prints from Britain to Tibet, some of which were distributed among other officers or gifted to Chinese officials. ${ }^{110}$ Not content to wait, other officers delighted in developing films themselves using small portable devices. These prints could then be pasted onto postcards and sent home to loved ones in Britain (figure 9). ${ }^{11}$ This traffic in photographs traveled via the expedition's chain of field post offices: mounted infantry carried the post between Lhasa, Gyantse, and Phari dzong, and from there runners recruited in Sikkim carried it along the treacherous route over the Himalayas to Siliguri, from which it traveled by overnight train to Calcutta. When the relay worked efficiently, a parcel took eight days to travel between Gyantse and Siliguri. ${ }^{112}$

When these prints and films reached Britain, they were published in periodicals in huge quantities, often as an implicit legitimation of the expedition. In its special supplement on the expedition's arrival in Lhasa in August 1904, the Sphere for example paired its photographs with Curzon's Guildhall speech defending his policy towards Tibet. ${ }^{113}$ Remarkably, these illustrated periodicals were then sent to Tibet during the expedition, returning the photographs to their photographers. Besides the periodicals received by the officer's mess, Bailey thanked his father for sending the Illustrated London News, which, along with the Daily Graphic and Black and White, contained hundreds of photographs by him or other officers. ${ }^{114}$ Some of these photographs are directly attributable to Bailey, matching perfectly negatives he described in his correspondence home. ${ }^{115}$ Apparently insufficient, Francis Younghusband added to the traffic by commissioning cuttings agencies to send articles on the

110 Frederick Bailey, letters of 2 Aug., 12 Aug., and 5 Sept. 1903, British Library, MSS Eur F157/163; 14 Jan. 1904, British Library, MSS Eur F157/164.

111 G. Preston, letter to wife, 10 Sept. 1904, National Army Museum, photograph scrapbook, diaries, and letters associated with Tibet, 1965-10-111-2; Lieutenant H. Mitchell sent versions of these from Tibet to his sister Sylvia in February 1904: H. Mitchell and W. Mitchell, letters and photographs associated with Tibet and other campaigns, 2006-12-60 (15).

112 D. S. Virk, Postal History of Indian Military Campaigns: Sikkim-Tibet, 1903-1908 (New Delhi, 1989), 29-34.

113 "Lhassa at Last," Sphere, 20 Aug. 1904: i-iv (supplement).

114 Frederick Bailey, letter to father, 20 Sept. 1903, British Library, MSS Eur F157/163. For a fractional sample, see "The Theocracy in the Clouds: Buddhist Monasteries in Tibet," Illustrated London News, 21 May 1904, 764; "With Younghusband in Tibet: Difficulties and Dangers of the Advance," Illustrated London News, 6 Aug. 1904, 194; "With the British in Tibet: The Monks of Gyangtse Promising to Assist the Mission with Supplies," Daily Graphic, 2 Aug. 1904: 4; "Tibetans Making Way for the British Mission at Phari Fort," Black and White, 2 Apr. 1904: 508; "The Tibetan Advance," Black and White, 9 Apr. 1904: 533.

115 The Daily Graphic published Bailey's photograph of the Chinese man "Wong," sent from Tibet a month earlier, and repeated his claim that the man was later deported for aiding the expedition. The letter to his mother further explained that the man had asked Bailey to take the photograph as "he hadnt [sic] been home for 20 years"; Bailey "never gave him the photo." "The Younghusband Expedition," Daily Graphic, 30 Jan. 1904: 4; Bailey, letter to mother, 22 Dec. 1903, British Library, MSS Eur F157/163. 


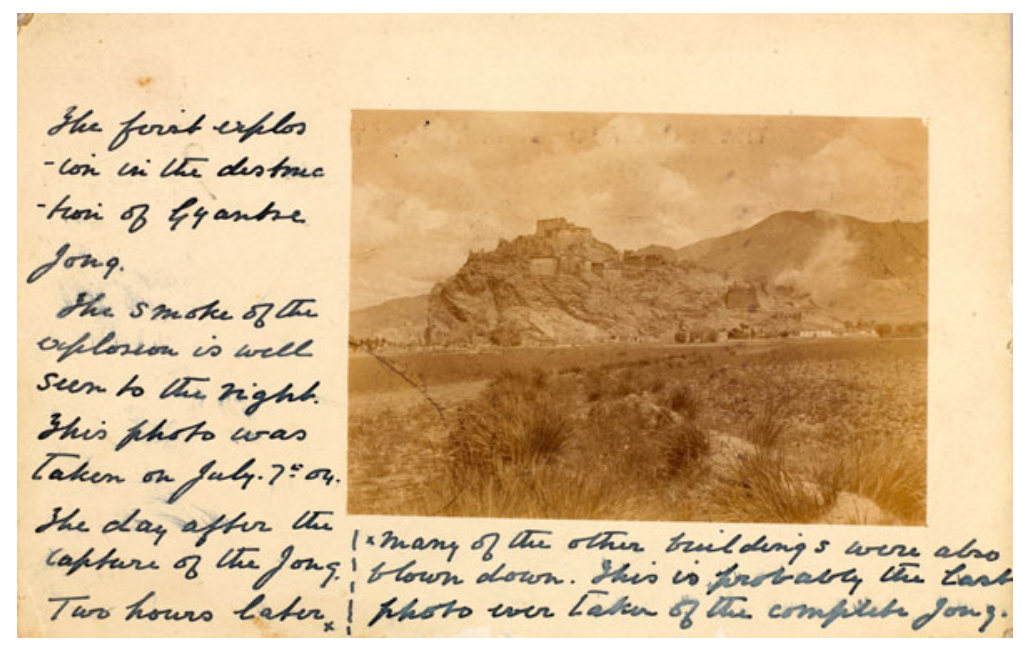

FiguRE 9 G. I. Davys, photograph of Gyantse dzong taken on 7 July 1904 and pasted onto a postcard sent on 9 November 1904. Source: loose collection of photographs associated with Tibet, 1977-01-37 (59), National Army Museum, London.

expedition from illustrated periodicals, representing an even wider selection that included the King, the Bystander, and the Sphere. ${ }^{116}$

What this circuit of photographs enabled was the physical re-presentation of action to those participating in events of photography, even while those events were still taking place in Tibet. The narrative by which self and other enjoined mutual responsibility was re-presented for interpretation, making each subject to the action they at the same time were carrying out. For some expedition members this raised uncomfortable truths. Frederick Bailey had always been ambivalent about the publication of his photographs in the press. He took photographs more as personal mementoes, to be given to him in an album as a birthday present from his father, than as records for publication. ${ }^{117}$ When his mother did send copies to the press he asked her to maintain his anonymity, claiming it was because he felt them of poor quality. ${ }^{118}$ Yet it was only when his photographs returned to him in published form that he was compelled to reinterpret his relation to Tibetans, both in terms of the violence enacted by the expedition and his role in the event of photographing it. In a letter to his mother, Bailey reiterated that he did not like that Black and White

116 Frederick Bailey, letter to mother, 24 Feb. 1904, British Library, MSS Eur F157/164; Francis Younghusband, Press Photographs relating to the Tibet Frontier Commission, 1904, British Library, MSS Eur F197/524.

117 Frederick Bailey, letter to father, 14 Jan. 1904, British Libarry, MSS Eur F157/164.

118 Frederick Bailey, letter to mother, 2 Aug. 1903, British Library, MSS Eur F157/163. 
had called him "their correspondent." He was especially at pains to emphasize that he did not like his mother "sending photos of dead people" to the press. ${ }^{119}$ This was a reference to photographs he had taken of Tibetans killed at Guru when a force armed only with matchlocks refused to disarm and was decimated by the British Maxim guns. The re-presentation of his relation with another, a relation which in the violent, photographed event and the subsequent event of photography called him to responsibility, made Bailey uncomfortable enough to disavow responsibility for both-and for the photographs showing this. The Guru massacre occurred on 31 March 1904, the photographs were published on 21 May, and the letter was sent on 17 June: a rapid turnaround between action and interpretation. ${ }^{120}$ It was a short time before the geographic circle of the photographs completed the "hermeneutic circle" they enacted.

It is harder to tell how much Tibetans were subject to the same circle of interpretation, but there is no better indication that they were than a photograph of two "reading" copies of the Pelican alongside a British officer (figure 10). The photograph's attempted humor depends on the irony that Tibetans in 1904 received no periodicals, and certainly not the Pelican. A weekly periodical of trivia snippets, it did not itself publish the expedition's photographs. Yet Tibetans did not need to see the end result of the event of photography in order to interpret it: all that was necessary was awareness that there was an end result. Their presence in this event referencing its own reproducibility, by itself, suggests they were aware of how events of photography exceeded, and returned to, their participants for interpretation, an interpretation of their relation to another and to the political imaginary of Tibet that could never be fixed.

\section{ONESELF AS ANOTHER}

If there is one photograph showing this awareness of photography's technical and political potential, it is that of the Jo-khang, the most sacred temple in Tibet and a key center of government, taken by John White after the expedition reached Lhasa (figure 11). The atmosphere on the streets was charged and tension within Tibet's government at its highest. Since the Chinese emperor had dismissed amban Yu-kang in November of 1902 the Qing court had exercised little authority in Lhasa. Although the tsongdu (national assembly) kept communications open with the new amban, Yu-tai, who only reached Lhasa in February 1904, it boldly asserted its independence in directing affairs with the expedition. ${ }^{121}$ The amban's weakness was partly due to the newly resurgent

119 Frederick Bailey, letter to mother, 17 June 1904, British Library, MSS Eur F157/164.

120 "The British Mission to Tibet," Daily Graphic, 21 May 1904: 761-63.

121 Letter from the tsongdu to amban Yu-tai, 3 July 1904, in Sanderson, "Transgression," appendix II. Although not disinterested, the autobiography of the son of the amban's secretary gives several incidences where the Tibetans directly overrode the amban's demands. Ts'an-chih Chen, "The Autobiography of Ts'an-chih Chen," in Peter Richardus, ed., Tibetan Lives: Three Himalayan Autobiographies (Richmond, 1998), 170; Captain William Ottley corroborates in his claim that the 


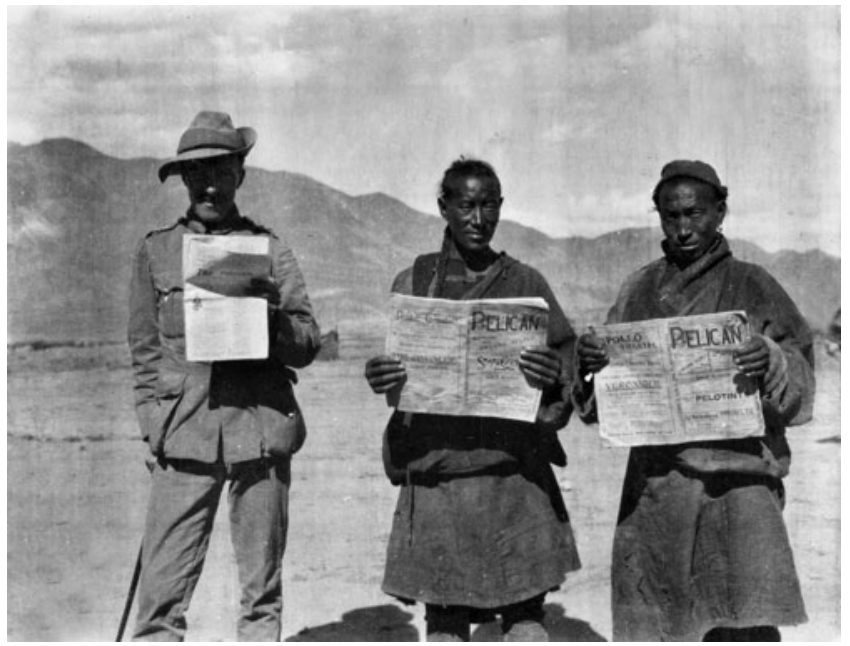

FigURE 10 L. Stone, uncaptioned. Source: loose collection of photographs associated with Tibet, 1980-07-139 (3), National Army Museum, London.

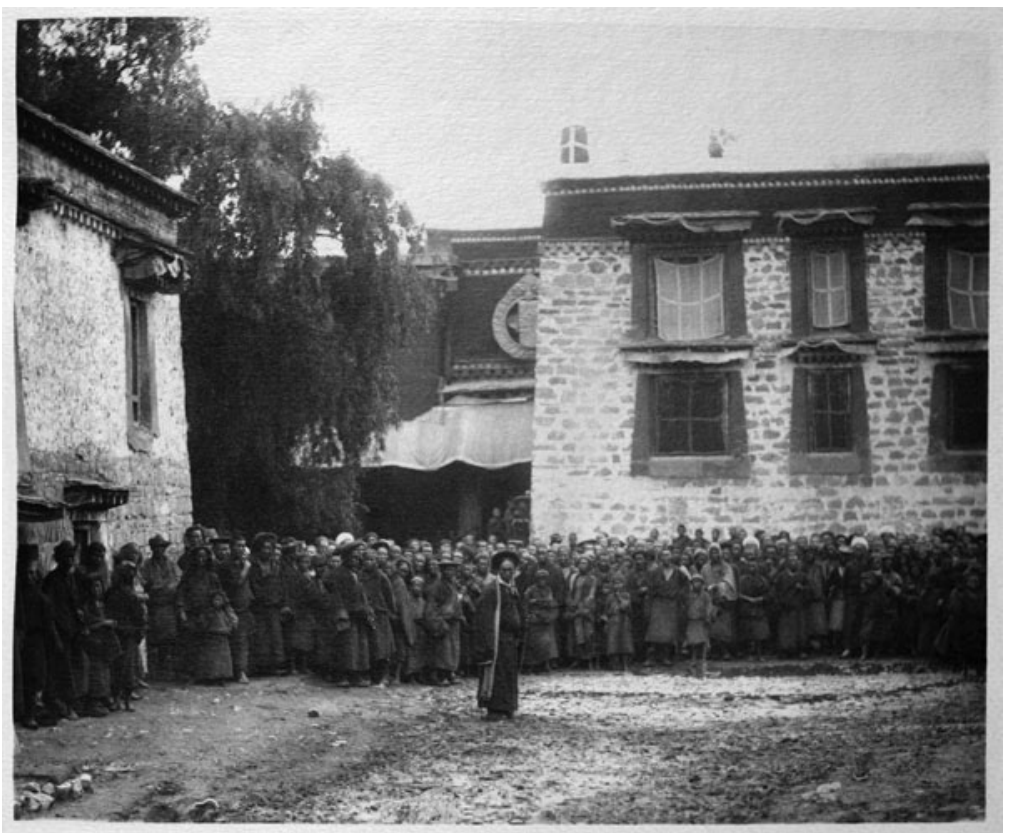

FIgURE 11 John Claude White, "A Street Scene in Lhasa." Source: Tibet and Lhasa, 2 vols. (Calcutta, 1908), II, (c) British Library Board, unnumbered, British Library, London. 
Dalai Lama, now in his majority, although this also caused fractures in the Tibetan administration itself. Shortly after the Dalai Lama assumed full temporal authority the ex-regent was imprisoned and, William O'Connor claimed, the friends of the Dalai Lama were raised to high political office. ${ }^{122}$ Whatever the truth in this claim, tensions deepened in October 1903 when the four shapes of the kashag insisted on negotiating with the British while the tsongdu urged war. $^{123}$ Incensed by its conciliatory attitude, the tsongdu had the whole kashag imprisoned on 13 October. ${ }^{124}$ Throughout the expedition's advance the Tibetan government painfully prevaricated over the best way to respond. Caught between wanting to exclude the expedition from Tibet altogether, and indeed taking an oath in January 1903 to do so by force if necessary, and recognizing the inevitability of the British advance as "a calamity sent by heaven," the government's indecision only amplified existing tensions. ${ }^{125}$ New shapes were appointed, but the Dalai Lama's flight to Mongolia in July 1904 left a weak and divided government to face the expedition when it entered Lhasa in August. Although Ti Rimpoche, a reincarnating lama of Ganden monastery, was nominated regent, his authority remained contested by the monks of Drepung monastery, who had been particularly vocal in opposing the Dalai Lama's recent policy decisions. ${ }^{126}$ It was a fraught time to be photographing the Jo-khang.

Conflicting accounts of the wrangling over British access to the Jo-khang expressed these tensions. According to Landon, the amban's secretary arranged admittance for the photography party, which consisted of himself, John White, and E. C. Wilton, the former consul of Chengdu, Sichuan. This Landon interpreted as an attempt to reassert Chinese authority over the Tibetans after access had been refused to the amban himself on 11 August. ${ }^{127} \mathrm{He}$ adds, "At any rate, to our surprise, a definite invitation was one day extended to one or two of the members of the Mission," but Landon does not specify whether this came from the amban or the Tibetan government. ${ }^{128}$ John White claimed twelve years later that, as resident of Sikkim, his connections with high-ranking monks gained

amban was even attacked and some of his retinue killed in Lhasa during the expedition. William Ottley, With Mounted Infantry in Tibet (London, 1906), 86.

${ }_{122}$ Wangchuk Deden Shakabpa, Tibet: A Political History (New Haven, 1967), 195; Frederick O'Connor, "Appendix D: The Present Condition and Government of Tibet," in Landon, Lhasa, II, 352-53.

123 Shakabpa, Tibet, 208.

124 Ibid.; Landon, Lhasa, II, 10.

125 Pledge of all Tibetan lay and monk officials on how to resist the foreigners, 25 Jan. 1903; and report to the Dalai Lama from the tsongdu on how to resist the British Army, 12 June 1904, both in Sanderson, "Transgression," appendix II, and 37-42.

126 Wendy Palace, The British Empire and Tibet, 1900-1922 (London, 2005), 9, 152 n23.

127 Landon, Lhasa, II, 302-3.

128 Ibid., 304. 
him special invitations to photograph the monasteries of Sera and Drepung, though he does not mention the Jo-khang. ${ }^{129}$ However, although allowing British access to the Jo-khang might have allowed the Tibetan government to rebuff the amban once more, it seems unlikely that it did so, given the Jo-khang's importance and the resentment at the expedition even being in Lhasa. The tsongdu's belligerence is partly explained by its conviction that merely the presence of "invaders of a different religion" in the "religious snowland," especially in sacred Lhasa, would cause Buddhism to be "wiped out as if by disease." 130

If Tibetans did provide access to the Jo-khang, this did not stop the photography party from raising hackles on that day. Upon leaving the Jo-khang, Landon recorded, the group was greeted by a "growling crowd," which the amban's secretary had to keep back with a monk wielding "a weighted 8-foot whip." The monk "struck out right and left, inflicting appalling blows on the packed crowd." The crowd responded in kind, stoning the departing group, although Landon claimed projectiles were aimed at the Chinese escort in "contempt" for Chinese suzerainty, and not at the British. Eager to claim a victory for Tibetan autonomy, Landon found this "convincing proof that no action of the Chinese with regard to Tibet will, in the future, have any real importance, or be regarded by the Tibetans as binding upon themselves in any way."131 Yet this disregarded that the crowd was indignant over the Tibetan government's impossible situation, caught between self-respect and necessary conciliation, British imperial aggressors and Chinese imperial possessors, and at the photographing of the Jo-khang that was its result.

White's photograph entirely captured and yet missed the point. Despite showing a large crowd restrained, he claimed, by the "Lhasa police force," he gave it the anodyne title, "A Street Scene in Lhasa." For White, as for Landon, photographing the Jo-khang was another occasion for demystifying the special distinction of "Lamaism," which they saw as underlying Tibet's failure to act as an independent nation-state: the event thus became "a street scene" like any other within the genre of street photography. ${ }^{132}$ As Younghusband finessed it, British visits to Lhasa's religious sites were efforts at " "peaceful penetration" to "break through the last barrier which separated us from the Tibetans." ${ }^{\prime 33}$ But the Tibetans participating in this event of photography cannot be reduced to passive extras in a British imaginary. The photograph did not simply take place on "The street leading to the Jo-kang," as Landon captioned it, but on the Barkor, one of the three processional routes ringing the temple

\footnotetext{
129 John White, “World's Strangest Capital," National Geographic Magazine 24 (Mar. 1916): 281; Younghusband, India and Tibet, 309.

130 Report to the Dalai Lama from the tsongdu, in Sanderson, "Transgression."

131 Landon, Lhasa., 315-16.

132 See John Thomson and Adolphe Smith, Street Life in London (London, 1877).

133 Younghusband, India and Tibet, 309.
} 
around which visitors perform a parikrama (ritual circumambulation). The second floor of the building to the right of the photograph houses the Panchen Lama's apartments, while immediately to the left is the principal, western entrance to the Jo-khang. A willow tree ostensibly planted around 641 by the Chinese wife of Songtsen Gampo, the Tibetan emperor instrumental in introducing Buddhism to Tibet, fronts the entrance. ${ }^{134}$ A short walk around to the south of the Jo-khang would take you to the offices of the kashag; to the east, the seat of the Nechung Oracle, the chief oracle in Tibet. ${ }^{135}$ Each of the elements composing this space held considerable spiritual meaning to the Tibetans photographed. ${ }^{136}$ It was not that Landon was unaware of this, but that he tried to reassign its significance: "All round the Cathedral [Jo-khang] the dirty and insignificant council chambers and offices ... lean like parasites against it for support, huddled together and obscuring the sacred structure, to which they owe their stability, in a way that seems mischievously significant of the whole state of Tibet."137 Yet precisely the emphasis on "significance" revealed that this was not how Tibetans regarded either the space or their role within it when it was photographed.

We must be careful: this encounter outside the Jo-khang was not Tibetans "resisting" their subordination within the event or their subordination when it was interpreted as a photograph. Neither was it Tibetans actively shaping the event's potential for interpretation by subsequent observers. The encounter, I think, entailed Tibetans receiving an interpretation of their action in the event and its political implications while it was being carried out. The distinctions are fine; the differences great. The fracas outside the Jo-khang entailed Tibetans receiving from the event, through their relation to the British photographer and imagined subsequent observers, a proposal to understand themselves and their relation to Tibet differently. It entailed a re-presentation to Tibetans of their own sacred definition of Tibet, with the Jo-khang at the mandala's heart, and, through their relation with another, their ability to interpret that definition.

Not every event of photography occasioned this hermeneutic of action and understanding. In many cases the events remained only the possibility for understanding, what Badiou calls "this almost non-existent something.",138 But merely through taking this possibility seriously we find new grounds for

134 André Alexander, The Temples of Lhasa: Tibetan Buddhist Architecture from the 7th to the 21st Centuries (Chicago, 2005), 28-29, 60; mK'yen brtse's Guide to the Holy Places of Central Tibet, Alfonso Ferrari, Luciano Petech, and Hugh Richardson, eds. (Rome, 1958), 39-40.

${ }^{135}$ Keith Dowman, The Power-Places of Central Tibet: The Pilgrim's Guide (London: New York, 1988), 48-49.

136 Michael Henss, The Cultural Monuments of Tibet: The Central Regions, 2 vols. (Münich, 2014), I, 45-88.

137 Landon, Lhasa, II, 302.

138 Badiou, Philosophy and the Event, 43. 
a critique of past and present narratives of Tibet that would deny it. The ringing of the Jo-khang with metal detectors since 2012 and the intensification of "patriotic education" classes emphasizing Tibet's inalienable historical relation to China - responses to the increasing severity of Tibetan protest, particularly through self-immolation, since March 2008 - makes this critique of agency in photography, and of the historical concept of Tibet contingent upon it, more important than ever. ${ }^{139}$ Almost non-existent, but not entirely so.

\begin{abstract}
This article rethinks the nature of power and its relation to territory in the photographic event. Focusing on thousands of photographs taken during the British Younghusband Expedition to Lhasa between 1903 and 1904, it reorients understandings of photography as either reproducing or enabling the "negotiation" or contestation of power inequalities between participants. It shows how, in the transitory relations between Tibetans, Chinese, and Britons during and after photographic events, photography acted as a means by which participants constituted themselves as responsible agents - as capable of responding and as "accountable"-in relation to one another and to Tibet as a political entity. Whether in photographs of Tibetans protesting British looting or of their "reading" periodicals containing photographs of themselves, photography, especially Kodak photography, proposed potential new ways of being politically "Tibetan" at a time when the meaning of Tibet as a territory was especially indeterminate. This article therefore examines how the shifting territorial meaning of Tibet, transformed by an ascendant Dalai Lama, weakening Qing empire, and Anglo-Russian competition, converged with transformations in the means of visually reflecting upon it. If photography entailed always-indeterminate power relations through which participants constituted themselves in relation to Tibet, then it also compels our own rethinking of Tibet itself as an event contingent on every event of photography, rather than pre-existing or "constructed" by it.
\end{abstract}

Key words: photography, instrumentality, territory, event, power, Tibet, Younghusband Expedition

139 Written statement submitted by the International Fellowship of Reconciliation, a nongovernmental organization with special consultative status, UN Human Rights Council, 22nd session, Feb. 2013, 2-4; Special Topic Paper: Tibet, 2008-2009, United States Congressional-Executive Commission on China (Oct. 2009), 32-33. 